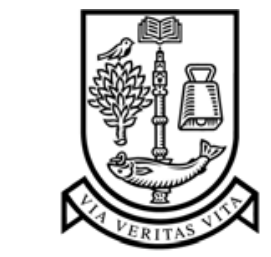 \\ UNIVERSITY \\ of \\ GLASGOW
}

Cohen, B. L. and Weydmann, A. (2005) Molecular evidence that phoronids are a subtaxon of brachiopods (Brachiopoda: Phoronata) and that genetic divergence of metazoan phyla began long before the early Cambrian. Organisms Diversity and Evolution 5(4):pp. 253-273.

http://eprints.gla.ac.uk/2944/ 
from: Organisms, Diversity \& Evolution (2005) 5: 253-273

\title{
Molecular evidence that phoronids are a subtaxon of brachiopods (Brachiopoda: Phoronata) and that genetic divergence of metazoan phyla began long before the early Cambrian
}

\author{
Bernard L. Cohen ${ }^{\mathrm{a}, *}$, Agata Weydmann ${ }^{\mathrm{b}}$ \\ ${ }^{a} I B L S$, Division of Molecular Genetics, University of Glasgow, Pontecorvo Building, 56 Dumbarton Road, Glasgow, \\ G11 6NU, Scotland, UK \\ ${ }^{\mathrm{b}}$ Institute of Oceanology, Polish Academy of Sciences, Powstancow Warszawy St., 55, 81-712-Sopot, Poland
}

Received 4 October 2004; accepted 22 December 2004

\begin{abstract}
Concatenated SSU (18S) and partial LSU (28S) sequences ( $\sim 2 \mathrm{~kb})$ from 12 ingroup taxa, comprising 2 phoronids, 2 members of each of the craniid, discinid, and lingulid inarticulate brachiopod lineages, and 4 rhynchonellate, articulate brachiopods ( 2 rhynchonellides, 1 terebratulide and 1 terebratellide) were aligned with homologous sequences from 6 protostome, deuterostome and sponge outgroups (3964 sites). Regions of potentially ambiguous alignment were removed, and the resulting data (3275 sites, of which 377 were parsimony-informative and 635 variable) were analysed by parsimony, and by maximum and Bayesian likelihood using objectively selected models. There was no base composition heterogeneity. Relative rate tests led to the exclusion (from most analyses) of the more distant outgroups, with retention of the closer pectinid and polyplacophoran (chiton). Parsimony and likelihood bootstrap and Bayesian clade support values were generally high, but only likelihood analyses recovered all brachiopod indicator clades designated a priori. All analyses confirmed the monophyly of (brachiopods + phoronids) and identified phoronids as the sister-group of the three inarticulate brachiopod lineages. Consequently, a revised Linnean classification is proposed in which the subphylum Linguliformea comprises three classes: Lingulata, 'Phoronata' (the phoronids), and 'Craniata' (the current subphylum Craniiformea). Divergence times of all nodes were estimated by regression from node depths in non-parametrically rate-smoothed and other chronograms, calibrated against palaeontological data, with probable errors not less than $50 \mathrm{My}$. Only three predicted brachiopod divergence times disagree with palaeontological ages by more than the probable error, and a reasonable explanation exists for at least two. Pruning long-branched ingroups made scant difference to predicted divergence time estimates. The palaeontological age calibration and the existence of Lower Cambrian fossils of both main brachiopod clades together indicate that initial genetic divergence between brachiopod and molluscan (chiton) lineages occurred well before the Lower Cambrian, suggesting that much divergence between metazoan phyla took place in the Proterozoic.
\end{abstract}




\section{Introduction}

The molecular phylogenetic exploration of brachiopod:phoronid relationships began with a disagreement between independent analyses of nuclear-encoded small subunit ribosomal RNA (18S or SSU) gene sequences. The first published result (Halanych et al. 1995), based on a single, cloned sequence from each taxon, suggested that a phoronid (Phoronis vancouverensis, syn. ijimai) was sister to the articulated (rhynchonellate) brachiopod, Terebratalia transversa. In contrast, a sister-group relationship of phoronids with inarticulate (linguliform) brachiopods was supported by the first analysis based on directly determined sequences from more than one specimen of each taxon (Cohen and Gawthrop 1996), and by a later analysis that included a freshly determined sequence from $P$. ijimai (Cohen 2000). The molecular affinity of both phoronids and brachiopods with protostomes has been less controversial, being supported by all SSU rDNA evidence and by additional molecular data from mitochondrial sequences and from other nuclear genes (Cohen et al. 1998a; de Rosa et al. 1999; Cohen 2000; Helfenbein 2000; Saito et al. 2000; Helfenbein and Boore 2003; Ruiz-Trillo et al. 2004). Although the (phoronid + brachiopod) clade has been questioned (Peterson and Eernisse 2001), existing evidence from SSU sequences supports the following conclusions: (1) both brachiopods and phoronids belong among the protostomes, their closest affinity being with molluscs and annelids; (2) no well-supported sistergroup relationship links brachiopods and phoronids with any other phylum; (3) brachiopods and phoronids form a generally well-supported clade, within which (4) a clade of (phoronids + inarticulate brachiopods) is moderately well supported; and (5) there is weak evidence for phoronids being the sister-group of craniiform inarticulate brachiopods.

In the present report we combine existing SSU sequences with about $2 \mathrm{~kb}$ of new data from the nuclear-encoded large ribosomal RNA subunit (LSU or 28S) gene for two phoronids and two members of each main brachiopod lineage. These sequences were selected because of the particular advantage of rRNA genes for deep phylogeny: that their cellular products have a relatively gene-, time- and lineage-invariant (but not necessarily domain-invariant) biological function, favouring homogeneity of the phylogenetic signal. By contrast, protein-coding genes may exhibit gene-, time-, lineage-, and domain-specific differences in selection pressure, as well as divergent paralogues, complicating the interpretation of their combined phylogenetic signal. The results of parsimony and likelihood analyses of our rDNA data strongly support the monophyly of (brachiopods + phoronids) and confirm that phoronids belong within brachiopods, as the sister-group of the three extant inarticulated lineages, i.e. craniids, discinids and lingulids (currently subphyla Craniiformea and Linguliformea of Williams et al. 1996; but see Proposed new classification below).

\section{Biological background}

Phoronids are widely distributed but uncommon, worm-like, marine, sessile protostomes. They generally develop from a distinctive larva, through a uniquely catastrophic metamorphosis, into a lophophorate adult. Typically, these inhabit a chitinous tube, which may be reinforced with mineral particles, packed into a dense lawn, or embedded in a substrate. About 12 extant species in two genera are recognised (Emig 1977a, 1979, 1982), and no ancient phoronid fossils are certainly known (Fenton and Fenton 1934; MacKinnon and Biernat 1970). Although the Lower Cambrian fossil Iotuba was originally described as a phoronid (Chen and Zhou 1997), this is now considered doubtful (Zhifei Zhang, pers. comm., 2004).

Brachiopods are bivalved, sessile, occasionally infaunal or interstitial, generally epifaunal or epibenthic protostomes. They were among the earliest mineralised fossils in the Lower Cambrian and have an excellent, continuous fossil record. Over 300 named species occur today, ranging from inter- or subtidal to abyssal depths in all oceans. Although patchily distributed, they may have high, local population densities. Two principal groups of extant brachiopods are differentiated by the way in which the paired shell valves join. In the numerically dominant 'articulated' forms (Rhynchonelliformea; Williams et al. 1996), the valves join at a mineralised hinge, whereas the shell valves of 'inarticulated' forms (Linguliformea and Craniiformea) lack a mineralised hinge and are connected by muscles.

In four taxa (bryozoans, phoronids, brachiopods and pterobranchs) the food-collecting organ is a tentacular lophophore. These were once treated as a supra-phylum "Tentaculata" or "Lophophorata" (e.g. Emig 1977b, and references therein; Hatschek 1888), but on molecular evidence pterobranchs have been relegated to the deuterostomes, whereas the other three phyla are placed with annelids and molluscs among the lophotrochozoan protostomes (Halanych 1995). A close relationship of ectoproct bryozoans to brachiopods and phoronids is not currently supported by molecular data. Although phoronids and brachiopods have traditionally been treated as separate phyla, some authors consider them to share a body plan (see Cohen et al. 2003, and references therein). While determining whether phoronids and brachiopods belong within the same or different phyla may seem esoteric, it merits clarification because it bears on the use of phoronids as the outgroup in cladistic analyses of brachiopod inter-relationships (e.g. Carlson 1995; Williams et al. 1996), on the 
understanding of their body plans, on the interpretation of characters and convergence in metazoan morphological evolution, and on taxon choice for future genome sequencing.

\section{Roles of participants}

AW undertook a substantial proportion of the benchwork and reviewed the manuscript. BLC obtained the specimens, planned and directed the study, trained AW in relevant laboratory methods, and was responsible for data analysis and presentation.

\section{Material and methods}

\section{Specimens and molecular methods}

Details of the specimens and sequences, including database accession numbers, are given in Table 1. Genomic DNA was extracted by protease digestion, solvent extraction and ethanol precipitation from ethanol-preserved specimens, redissolved in TE (10 mM Tris, $1 \mathrm{mM}$ EDTA, $\mathrm{pH} 7.5)$, and stored at $4{ }^{\circ} \mathrm{C}$ (Sambrook et al. 1989). Selected gene sequences were amplified by polymerase chain reaction using commercial reagents (Promega, UK) and the manufacturer's recommended conditions. Newly determined SSU regions were amplified in three overlapping fragments as described by Cohen et al. (2004). The sequenced LSU region was also obtained in three overlapping fragments, using amplification and sequencing primers from published descriptions (Hillis and Dixon 1991; Mallatt and Winchell 2002), but renumbered according to their forward $\left(5^{\prime}\right)$ or reverse $\left(3^{\prime}\right)$ positions in the articulate brachiopod Terebratalia transversa LSU sequence (GenBank accession AF342802), as follows: forward primers F700, F1033, F1483, F1818, F2118; reverse primers R1007, R1039, R1460, R1797, R2105, R2743. Satisfactory amplification was generally obtained with an annealing temperature of $50^{\circ} \mathrm{C}$, but occasionally required a few initial cycles at $45^{\circ} \mathrm{C}$ followed by continued amplification at $55^{\circ} \mathrm{C}$. Amplification products were purified by electrophoresis in $1.0 \%$ agarose gel, recovered from a gel slice with a silica/chaotrope spin column (Qiagen, UK), and eluted in buffered water. Templates were sequenced on both strands by the in-house sequencing service using standard procedures (see Cohen et al. 2004). Except for some short, conserved terminal stretches read only once (and excluded from analysis unless they unambiguously matched well-determined sequence from a related taxon), each sequence was read from each strand at least twice and generally three or more times. Base-call ambiguities were resolved by comparison of electropherogram traces, with rare use of standard ambiguity codes. Terminal primer sequences were excluded from analysis, but internal primer sites were retained if confirmed by read-through.

\section{Sequences, data-editing and alignment}

Regions were selected for sequencing as follows.

(1) Quasi-complete, nuclear-encoded, ribosomal small subunit rDNA (18S or SSU rDNA), because it is widely used to resolve the high-level relationships of metazoans and has been used in several attempts to place brachiopods and phoronids in relation to other phyla (Halanych et al. 1995; Cohen and Gawthrop 1996, 1997; Cohen et al. 1998a,b; Cohen 2000; Mallatt and Winchell 2002). However, this sequence alone is unable to resolve the inter-relationships of most lophotrochozoan, protostome phyla with strong support (e.g. Adoutte and Philippe 1993; Abouheif et al. 1998).

(2) Nuclear-encoded, large subunit rDNA (23S or LSU rDNA), because complete sequences have recently been found to add usefully to the resolution of protostome phyla (Mallatt and Winchell 2002). However, resource limitations restricted work to only part of this $>3 \mathrm{~kb}$ sequence. The location of the most informative major portion was determined by counting the numbers of parsimony-informative sites in an alignment of five lophotrochozoan LSU sequences (the brachiopod AF342802, the phoronid AF342797, the bivalve AF342798, the annelid AF212166, and the echiuran AF342804). There were 204, 123 and 87 parsimony-informative sites, respectively, in $5^{\prime}$, middle, and $3^{\prime}$ segments, each of about $1 \mathrm{~kb}$, defined by existing primers. Thus, it was concluded that the 5' two-thirds of the LSU sequence would be most cost-effective (ca. $2.1 \mathrm{~kb}$ between primers F700 and R2743, numbered as in AF342802). This segment contains variable regions separated by strongly conserved blocks that facilitate alignment.

Sequences were manipulated and curated in the sequence editors SeqApp 1.9a (Gilbert 1993) and MacGDE (Smith et al. 1994b; also http://www.su.edu/ $\sim$ lintone/macgde/); basic alignments were constructed with Clustal-X 1.81 (Thompson et al. 1997). Alignments were prepared for analysis both including and excluding potentially misaligned sites, which were identified and removed using Gblocks 0.91 (Castresana 2000), with default and recommended block-length parameter settings and all gapped sites excluded. The retained and excluded blocks and the parameters used are shown in Organisms Diversity and Evolution Electronic 


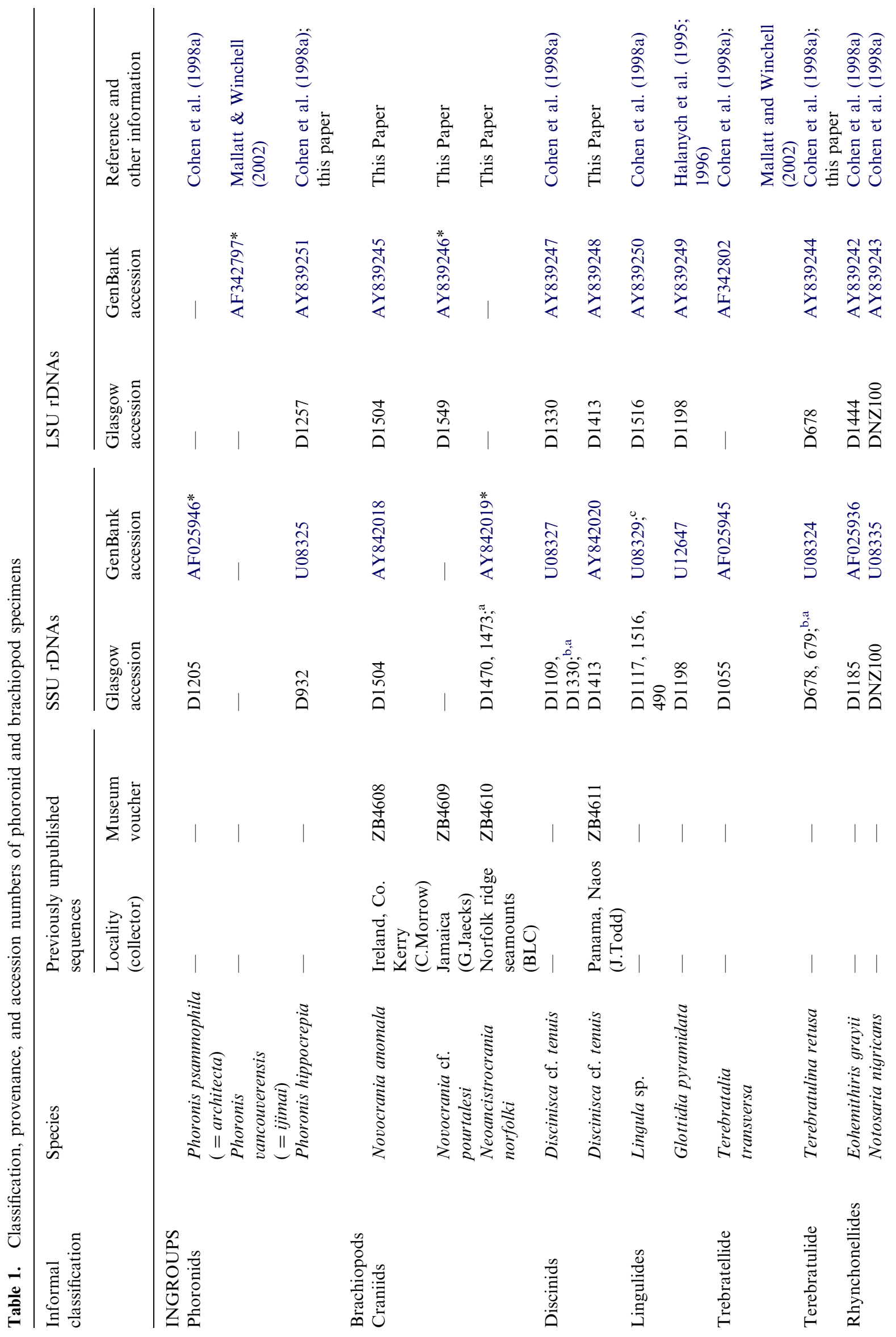




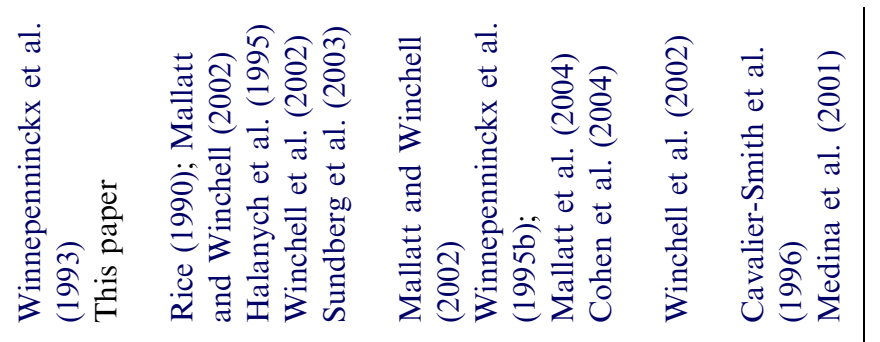

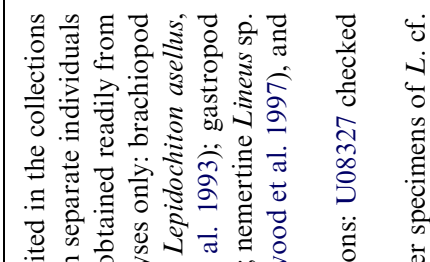

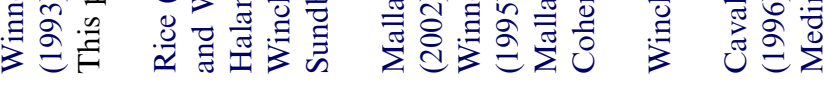

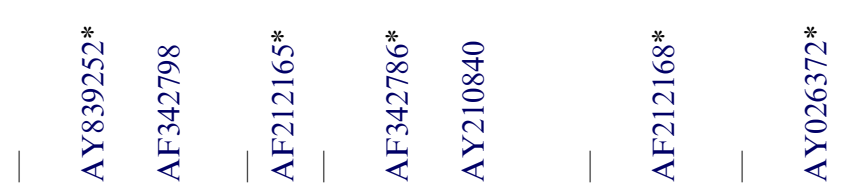

$\mid \frac{\sqrt{n}}{n}$<smiles>[V]=C[Tl]</smiles>

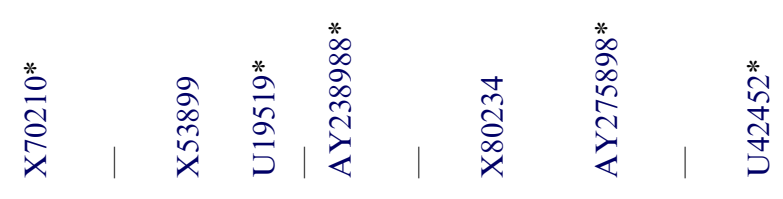

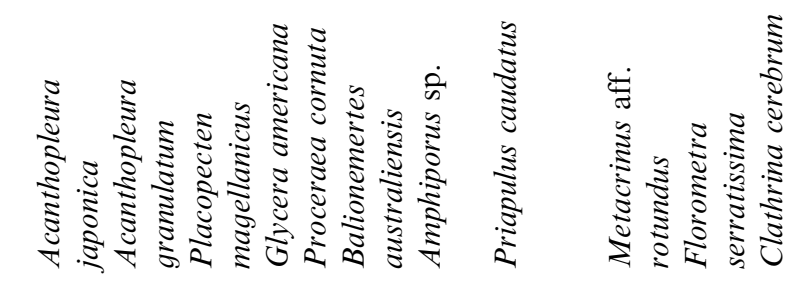

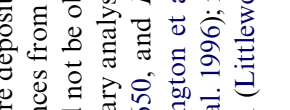

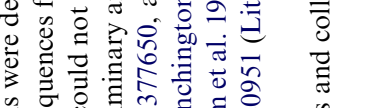

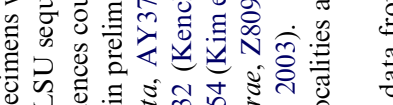

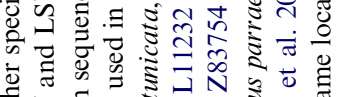

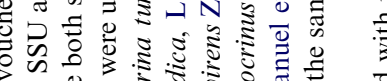

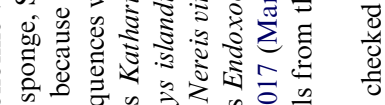

की

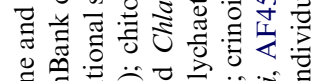

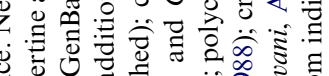

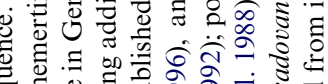

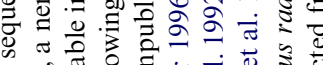

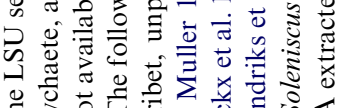

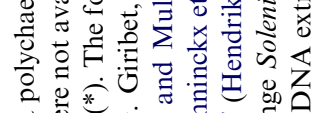

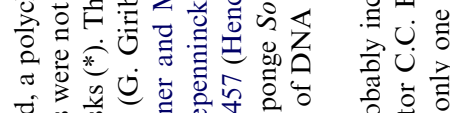

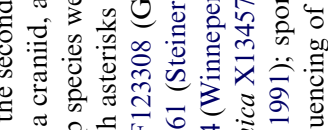

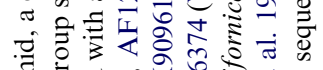

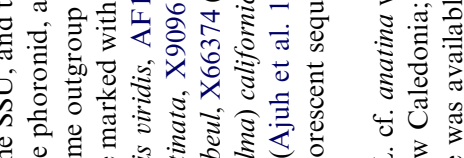

竞

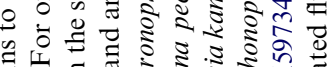

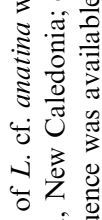

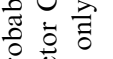

总尊

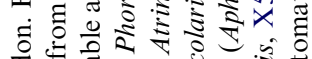

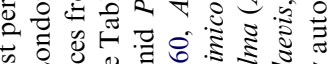

चु

焉号

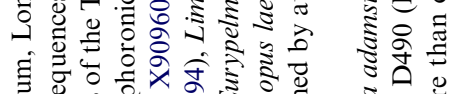

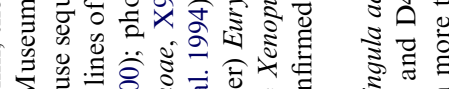

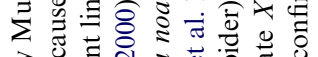

递苟

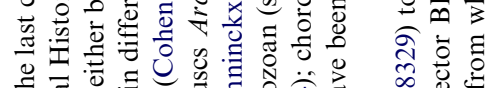

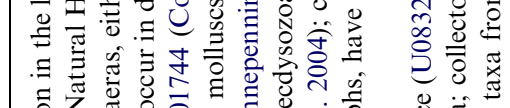

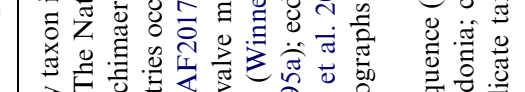

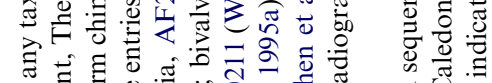

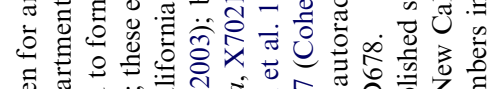

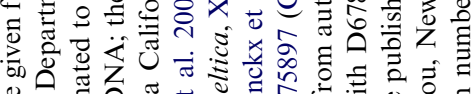

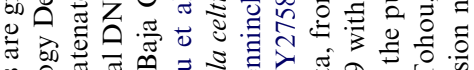

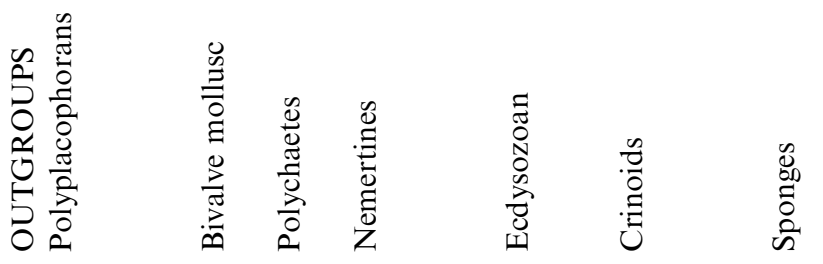

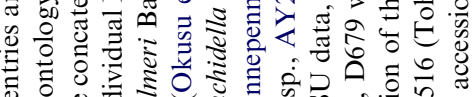

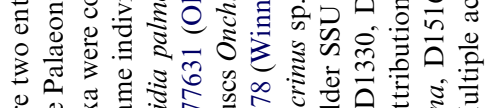

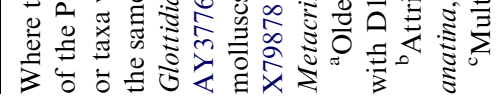


Supplement 05-11, Pt. 1, and described below. New sequences have been deposited in GenBank (see Table 1 for accession numbers).

\section{Alignment of SSU sequences}

The ingroup and outgroup were simultaneously aligned using Clustal (gap penalties open/extend 10/ 0.1, discussed in Cohen et al. 2004). Regions that showed appreciable length variation were then realigned manually, guided by the taxonomically nearest secondary structure model (for the gastropod Onchidella; Winnepenninckx et al. 1994), to ensure that terminal loops and helix-closing nucleotides were aligned while conserving base sequence homology, with length variation (minor in the ingroup) being accommodated, as far as possible, in stem regions. This procedure attempts to combine hypotheses of functional and positional homology and was applied to the length-variable helices $6,10-1$, and 49. Because of the absence of a clearly relevant model for the helix 23 variable region, this was aligned only by base-sequence similarity. The described alignment procedure was almost unnecessary in the present study, because the variable regions involved were largely excluded from analysis by subsequent application of Gblocks. Elsewhere, Clustal gave a compact, unambiguous alignment with short, largely autapomorphic indels. Automated base calls (but not older autoradiograph reads) at most such autapomorphic indels in conserved regions, were re-checked. The SSU sequences were also aligned using the high gap penalties selected for LSU alignment (see below).

\section{Alignment of LSU sequences}

No taxonomically close secondary-structure model was available, nor was one needed, because alignment ambiguity was confined to the more variable blocks for which no canonical structure is likely to exist. Gap penalties appropriate for Clustal alignment were determined by exploratory analyses of the ingroup, as follows. Pairwise alignments were made with high gap penalties so as to minimise indels, using disparate ingroup taxa ranging from inter-phylum (phoronid:brachiopod) to inter-species/population (e.g. discinid:discinid). Apart from the ingroup D7 region where some longer indels occurred, length variation was accounted for by scattered, notably short, indels, the numbers and sizes of which were recorded (see Results). Pairwise alignments were also made with a range of gap penalties, but lower penalties did not alter indel number or size. Low gap penalties did, however, increase indel number and size in multiple alignments of ingroup and outgroup sequences. To obviate chance differences that might be introduced by separate alignment of the ingroup with each separate outgroup, the LSU sequences were all aligned simultaneously, followed by manual correction of a few discrepancies. In light of the observed preponderance of short indels, the artificial introduction of indels was avoided by the adoption of high gap penalties $($ all $=10)$ for this alignment. This procedure will introduce some erroneous site homology, but because indels in pairwise alignments are both short and few (see Results), such errors should also be infrequent. The working alignment is available as a NEXUS-format file (Maddison et al. 1997); see Electr. Suppl. 05-11, Pt. 2.

\section{Concatenation of SSU and LSU sequences}

After separate alignment of SSU and LSU sequences and addition of single N's to mark gene boundaries, the LSU sequences were appended to the SSU ones (details in Table 1). In the few cases where SSU and LSU sequences from congeneric species or confamilial genera were concatenated, monophyly may safely be assumed (Malia et al. 2003). The principal phylogenetic analyses were performed on this alignment after the removal of potentially misaligned sites by Gblocks, and the excluded sites were saved for separate phylogenetic analysis. The alignment, with included and excluded sites marked, is presented in Electr. Suppl. 05-11, Pt. 1.

\section{Phylogenetic methods}

Alignment gaps were treated as missing data or excluded. Non-random data structure was assessed in PAUP* 4b11 (Swofford 2000) by the PTP test with 100 Branch-and-Bound (B\&B) replicates. Base compositional heterogeneity was assessed with the $\chi^{2}$-test in PAUP* on the complete alignment and on subsets of taxa. Saturation was tested by plotting uncorrected pairwise $(p)$ transition distance against transversion distance and fitting the correlation line (linear, power, etc.) that gave the highest $r^{2}$ value. Phylogenetic analyses using $\mathrm{B} \& \mathrm{~B}$ or heuristic searches with closest taxon addition and tree bisection and reconnection (TBR) branch exchange were performed in PAUP* on all sites and on informative sites only. Similar search procedures were used for bootstrap analyses, on 100-500 pseudoreplicates. Random addition sequence (100 replicates) gave the same most parsimonious tree. The maximum likelihood (ML) models that best fitted the data were identified under both the hierarchical likelihood ratio test (hLRT) and Aikake information (AIC) criteria in Modeltest 3.06 (Posada and Crandall 1998; Posada 2001; Posada and Buckley 2004); subsequent ML heuristic analyses were performed with a neighbor-joining starting tree, followed by TBR branch exchange. ML analyses were outgroup rooted except 
when the molecular clock was enforced. Likelihoods of alternative tree topologies were compared in Paup*4 using the S-H one-tailed test (with 10,000 replicates and RELL sampling; Shimodaira and Hasegawa 1999) on tree-files constructed in MacClade 4 (Maddison and Maddison 2001). Lineage relative rate tests were performed with RRTree 1.1.13 (Robinson et al. 1998), with individual taxa treated separately or assigned to taxonomic lineages, as appropriate. This program uses Fisher's exact test as an indicator of significant rate variation.

Bayesian maximum likelihood (BML) analyses used MrBayes 3.0b4 (Ronquist and Huelsenbeck 2003), with default priors and Markov chain settings, analysing all sites of the Gblocks-selected, concatenated SSU + LSU alignment as a single partition and as separate SSU and LSU partitions with partition-specific models identified by MrModeltest (Nylander 2004), i.e., in each case with six rate parameters, and with gamma shape parameter and invariant site frequency estimated from the data. Autocorrelated gamma and covarion models were also tested, and some analyses also were made with a 2-rate model. Trees were sampled every 100 for $10^{6}$ or $10^{5}$ generations and each analysis was run more than once. In all replicate runs the consensus topology was similar or identical, and a plateau of $-\ln L$ and all other recorded parameters was reached within ca. 3000 generations. The trees sampled up to 4000 generations were discarded as 'burnin', and a majority rule consensus tree was constructed from the remainder, using MrBayes (command sumt) or PAUP*.

The existence of a global molecular clock was assessed by a likelihood ratio test (LRT; references in Hillis et al. 1996) comparing ML heuristic search trees with and without the clock enforced, using the Modeltest-selected model appropriate for the alignment. For time-calibration of divergence points, ML trees found by PAUP* or MrBayes were transformed by the non-parametric rate smoothing (NPRS) or penalised likelihood (PL) methods using the program r8s (Sanderson 2003). Both Powell and TN algorithms were tested, with the smoothing parameter for PL (1.0) selected by crossvalidation. The deepest node, representing divergence between the chiton root and the ingroup, was set to age $=1.0$, so that younger nodes would be calibrated in proportion (see Results and Table 2 for node depths). Trees for r8s analysis were saved from PAUP* or MrBayes with branch lengths and both pectinid and chiton outgroups. The pectinid was then deleted in r8s, leaving the chiton as root. Confidence intervals (95\%) on selected node depths were estimated using the likelihood surface curvature method, with s-unit cutoff value 4.0 (as recommended). An attempt was also made to estimate divergence times for selected nodes by the quartet method, using Qdate 1.11 (Rambaut and Bromham 1998). Earliest and latest times of lineage or taxon origin were extracted from the revised brachiopod Treatise (Kaesler 1997-2002 and in press), generally with advice from brachiopod palaeontologists (see Acknowledgements). Where the origin of a taxon or lineage was associated with a particular stratigraphic stage, its boundary ages were used as maximum and minimum ages of origin. Where more than one stage or two different criteria were involved, the lowermost and uppermost boundary ages were used (Table 2). Boundary ages were taken from the 2004 International Stratigraphic Chart (Gradstein and Ogg 2004; Gradstein et al. 2004) and the A-Z stage list available at http:// www.stratigraphy.org. Although lower stage boundaries were used pragmatically to date lineage origins, the actual times of genetic divergence invariably predate first fossil appearances, and may equally predate lower stage boundaries by unknown periods of time.

Incongruence between SSU and LSU partitions was investigated with the ILD test in Paup*4 (100 replicates, heuristic search) and by comparing Bayesian analyses with partition-specific models. Phylogenetic signal conflict was assessed in Splitstree 2.4 (Huson 1998), using all variable sites of the concatenated SSU + LSU alignment (14 taxa) and testing all available splits methods and distance calculations. Because only trivial conflict was found, results are not shown. Statistical analyses and graph plotting were done with Cricket Graph III (Computer Associates, USA) or Minitab 10Xtra (Minitab Inc., USA).

\section{Taxon selection and rooting procedures}

The 12-taxon ingroup comprised two phoronids, two members of each of the craniid, discinid, and lingulid (inarticulated) brachiopod lineages, two rhynchonellide articulates (representing the rhynchonellate clade with simple or no lophophore supports and impunctate shells) and one each of terebratulidine and terebratellidine articulates (representing the rhynchonellate clades with more complex lophophore supports and punctate shells). Only one important articulate brachiopod lineage (thecideidine) was absent, because high-quality LSU sequence data were not yet available.

Outgroup taxon selection was controlled by the need to include a range of other protostomes (especially lophotrochozoans) and some more distant taxa, that would allow the new analyses scope to refute the close brachiopod:phoronid relationship anticipated from previous SSU results, and to permit effective outgroup rooting. Previous analyses of brachiopod and phoronid SSU sequences were rooted using data from the chiton Acanthopleura japonica (alone or in combination), selected because it was then the closest available outgroup (Cohen et al. 1998a; Cohen 2000). Although Acanthopleura now appears not to be basal amongst 


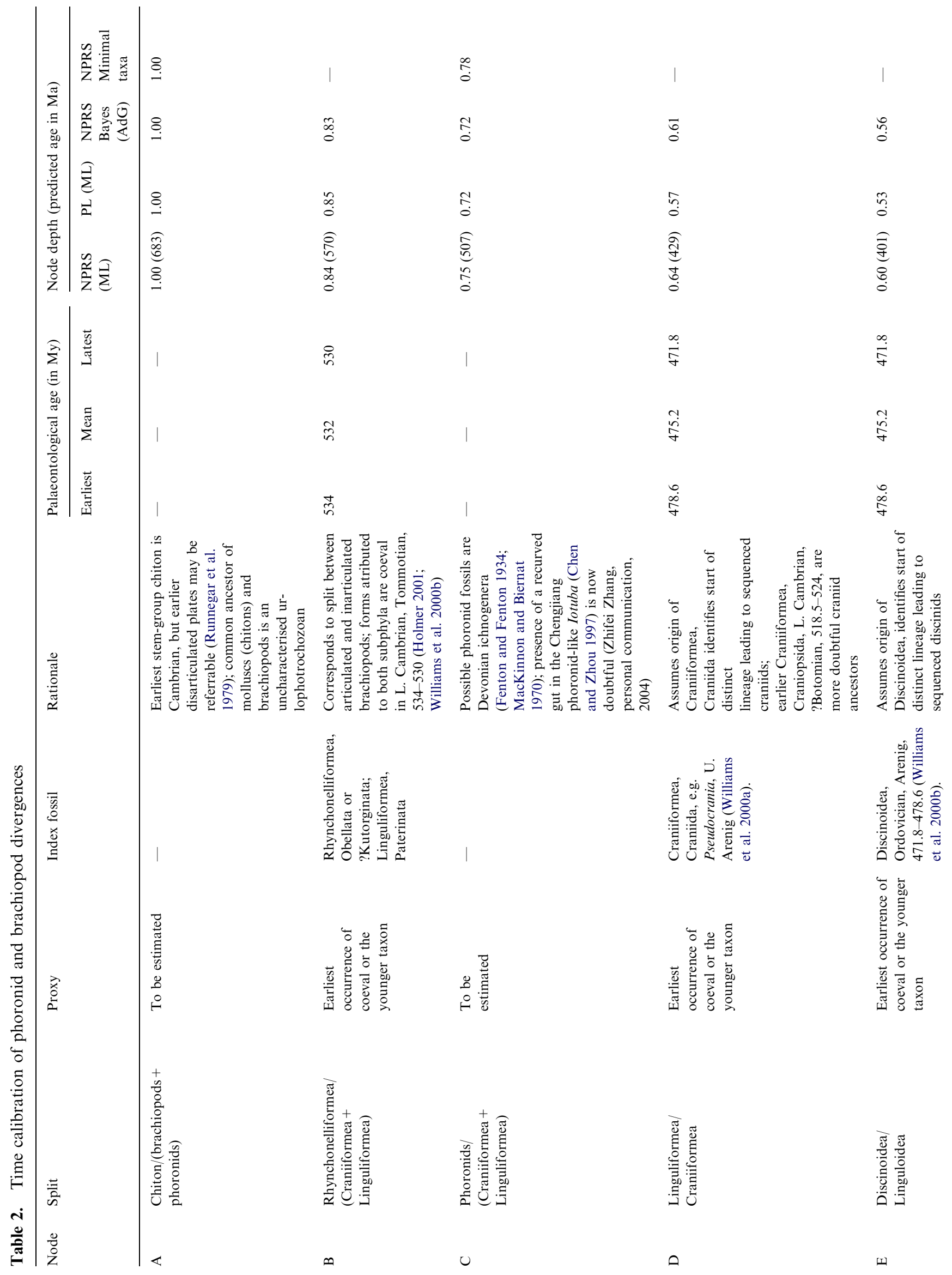




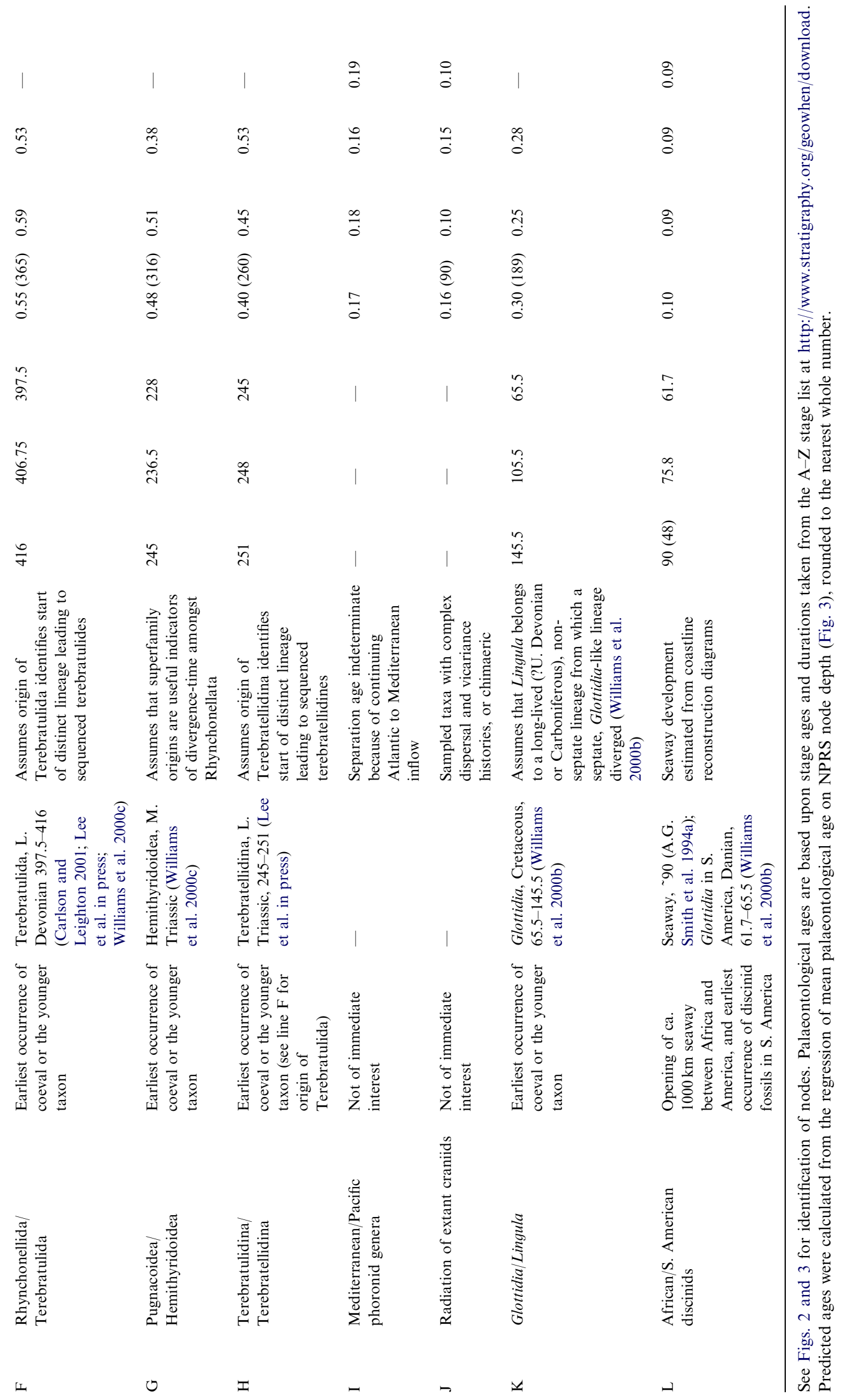


Polyplacophora (Okusu et al. 2003), suggesting that it may not be the most appropriate chiton outgroup, a parsimony tree of ingroup plus representative chiton SSU sequences showed that the patristic distance from it to the ingroup node remained among the shortest. Acanthopleura was therefore retained as a representative chiton, and the required portion of the LSU gene sequence was obtained from a congeneric species, $A$. granulatum. Sequences from the following more distant outgroups were also included: a pectinid bivalve mollusc, a polychaete annelid, a nemertine, an ecdysozoan (priapulan), a deuterostome (crinoid), and a sponge (details in Table 1), making a total of six distant outgroups. In each case, where multiple representatives of any taxon were available, preference was given to those with short branches in previous analyses. In addition to the concatenated SSU + LSU sequences just described, several additional phoronid, brachiopod and outgroup SSU sequences were included in preliminary analyses (not shown). Because of the large divergence between sponge and bilaterian SSU sequences, the sponge was used only in some preliminary analyses intended to explore and define the problems and potentialities of the data.

Because of the wealth of information available on brachiopod evolutionary biology (Kaesler 1997-2002 and in press), failure to recover key relationships (Rowell 1982; Carlson 1990, 1995; Cohen and Gawthrop 1996, 1997; Kaesler 1997-2002 and in press; Cohen et al. 1998a, b; Cohen 2001) could be used to identify analyses yielding suboptimal topologies. These expected relationships were: (1) that articulate brachiopods should (a) be the sister-group of inarticulate brachiopods and (b) divide into two subclades, one with a loop, the other without; (2) that discinid and lingulid inarticulate brachiopods should form a clade. Discinids and lingulids are the only extant forms with chitinophosphatic shells, long-lived, planktotrophic juveniles, and Early Palaeozoic origins. Moreover, extant discinids and many extinct lingulids share a distinctive, mosaic ornamentation of the earliest larval shell, in the former by silica tablets, in the latter of unknown composition (Williams et al. 1998, 2001).

\section{Results}

\section{SSU and LSU sequences treated separately}

\section{SSU alone}

Extensive preliminary phylogenetic analyses (maximum parsimony, maximum likelihood and Bayesian) of the SSU ingroup alignment showed that despite the presence of additional taxa and exploration of a wide range of alignment and phylogenetic parameters, resolution of phoronid:brachiopod relationships was no more certain than previously described for analyses with this gene. Moreover, some more distant outgroups gave aberrant tree topologies in which molluses and brachiopods were paraphyletic, with the chiton and pectinid on a branch placed between inarticulate and articulate brachiopods. The effect of varying alignment gap penalties was also explored. For example, when aligned with the same penalties selected for LSU (see below), and following exclusion of potentially misaligned sites by Gblocks, ML analyses of the ingroup + chiton + pectinid SSU sequences with the AIC-selected model $(\mathrm{GTR}+\mathrm{I}+\mathrm{G})$ gave very similar results, and included the (craniid + phoronid) clade with $64 \%$ bootstrap support. Since these analyses revealed nothing new or useful, details are not shown.

\section{LSU alone}

Alignment of the more variable regions of the LSU sequences was anticipated to need special attention. For this purpose, the distribution of the irreducible minimum numbers and lengths of indels differentiating ingroup taxa was recorded (by counting apparent deletions) for 18 pairwise Clustal alignments selected to cover the available range of taxonomic disparity. The same indels were observed with high or lower gap penalties (open/extend, $10 / 5$ to $5 / 0.1$ ). In a sample of these pairwise alignments, deletions $(n=113)$ were equally distributed between members of each taxon pair $\left(\chi^{2}=0.08,1 \mathrm{df}, 0.75>P>0.80\right)$ and were hierarchically distributed between taxa (mean number of indels: between phoronids and brachiopods, 11.75, $n=4$ comparisons; between articulate and inarticulate brachiopods, 12.0, $n=1$; between brachiopod genera, 6.0, $n=4$; between brachiopod species or populations, 1.7 , $n=6$ ). In one scan of all 18 pairwise alignments 174 indels were counted, 125 of length $=1$ nucleotide; 24 of length $=2 ; 8$ of length $=3 ; 5$ of length $=4 ; 4$ of length $=5 ; 7$ of length $=6-10 ; 1$ of length $>10$. In a similar analysis of outgroup sequence pairs, the distribution was similar in shape, though with more indels in each pair. Both distributions were good fits to markedly concave power curves (ingroup $r^{2}=0.89$; outgroup $r^{2}=0.88$ ). A similar distribution of intron indel lengths in Drosophila has been reported (Keightley and Johnson 2004, Table 1 and Fig. 2). The bias towards short indels, lack of extensive length variation despite much sequence variation, and the existence of a broadly canonical secondary structure model for eukaryotic LSU rRNAs (Schnare et al. 1996) together imply that sequence length is constrained, even in the highly variable loop regions. This indicates that our use of high alignment gap opening and extension penalties is justified. The validity of extending this alignment 
approach to include at least the closer outgroups was confirmed by the finding that indel length distribution in the (ingroup + mollusc) alignment closely matched ingroup, outgroup and Drosophila intron pairwise distributions (pairwise correlation coefficients in 4 comparisons, $0.93<r<0.99$ ).

\section{Concatenated SSU + LSU sequences}

\section{Alignment properties}

The alignment comprised 12 ingroup and 6 outgroup sequences, as described above (and see Table 1). It spanned 3964 sites, including single N's added to mark the start and end of each component sequence. There was no significant base composition heterogeneity between taxa $(\mathrm{A}=0.235, \quad \mathrm{C}=0.244, \quad \mathrm{G}=0.299$, $\mathrm{T}=0.222 ; 18$ taxa, $P=0.97$; ingroup reduced to one member of each main lineage, 12 taxa, $P=0.95$; one phoronid plus all 6 outgroups, $P=0.44$ ). Because there were some variable regions in which the alignment was considered to be potentially ambiguous, Gblocks was used to separate the alignment into retained and excluded blocks, adopting the suggested default parameters (some vary with the number of taxa) as follows: conserved positions present in at least 10 sequences $(10 /$ $18=55.6 \%$ ), retained flank positions present in at least 15 sequences $(83.3 \%)$, contiguous non-conserved segments longer than eight positions rejected, minimum retained block length five positions, all positions with gaps rejected. These parameters led Gblocks to retain 64 blocks comprising 3275 positions (83\% of the original alignment), in which base sequence was homogeneous $(P=0.99)$ and saturation was slight (Fig. 1). The retained alignment contained significant non-random structure (PTP test, 100 heuristic search replicates, all taxa, $P=0.01)$. To this alignment, the SSU gene contributed 1614 sites, of which 1207 were constant, 237 variable but not parsimony-informative, and 170 were parsimony informative. The LSU gene contributed 1661 sites, 1052 constant, 232 variable but uninformative, and 377 parsimony-informative sites. Thus, the LSU partition was considerably more informative than the SSU one. The ILD test found no significant conflict between the partitions $(P=0.35)$.

\section{Parsimony analyses}

Parsimony analyses of this 18-taxon, 3275-position alignment (both all sites and informative sites only) with the deuterostome (crinoid) outgroup gave a single tree in which the molluscs (pectinid and chiton) were unexpectedly paraphyletic as described above. In these trees, the expected relationships of deuterostome, ecdysozoan and polychaete were found (i.e. as in Mallatt and Winchell 2002), suggesting that the alignment itself was not suspect. Similar results were obtained when the other

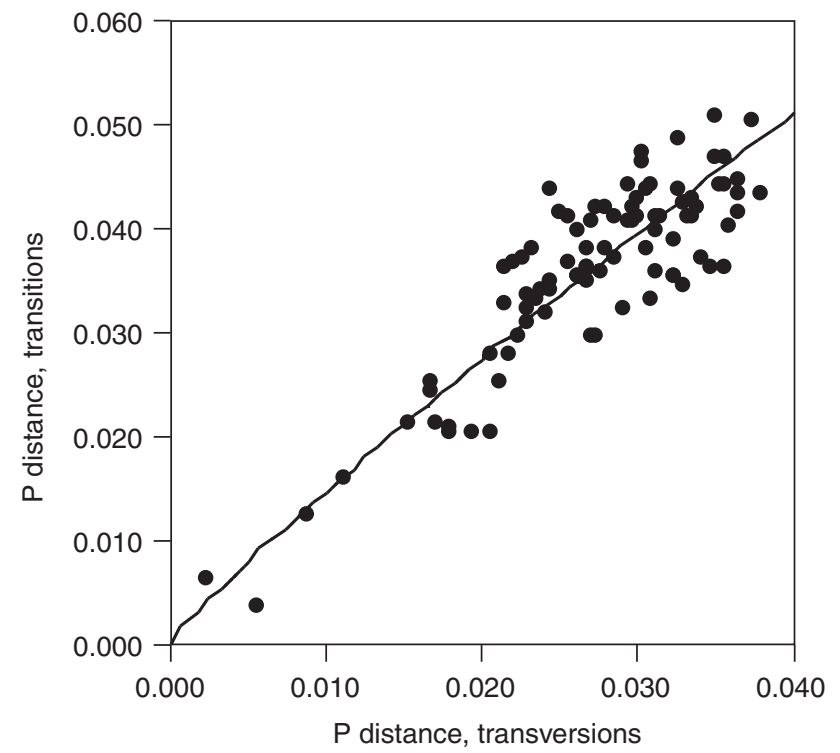

Fig. 1. Saturation analysis of concatenated SSU + LSU alignment of 12 ingroup and 2 mollusc outgroup sequences. Uncorrected $(p)$ transition distance plotted against uncorrected transversion distance for 91 pairwise comparisons. The distribution is well fitted by an almost linear power curve, $r^{2}=0.83$

more distant outgroups (polychaete, nemertean, priapulan) were used as sole outgroup in turn or in various combinations. Paraphyly of the comparatively shortbranched molluscs and the long branches leading to the other outgroups suggested that the unexpected topology was caused by taxon-specific differences in rate of evolution. The alignment was therefore analysed with RRTree, both with each taxon treated as a separate lineage (17 lineages, crinoid outgroup), and with them taxonomically grouped. When treated separately, all but one of the relative rate tests involving the polychaete, nemertean and priapulan showed that these were very significantly faster-evolving than the remaining taxa $(P \ll 0.001)$, whereas among tests not involving these taxa, 59 were not significant, $P>0.05,21$ were significant at $P<0.05$, and 3 at $P<0.01$. RRTree analysis with taxonomically defined groups confirmed this result. It was therefore concluded (regardless of possible correction for multiple statistical tests) that the crinoid, polychaete, nemertean, and priapulan sequences were too divergent to be reliable outgroups for resolution of brachiopod and phoronid relationships, whereas the pectinid and chiton molluscan sequences were potentially usable, the chiton having the fewest significant rate differences. All further analyses were therefore made with the four most divergent taxa excluded.

When relative rate tests were repeated with the ingroup taxonomically grouped, significant rate differences were 
noted between discinids, lingulids, craniids and the articulated brachiopods, and between craniids and phoronids $(P<0.05$, chiton outgroup). When ingroup sequences were tested individually, Notosaria and Glottidia each stood out as relatively fast-evolving. However, although Notosaria is on a long branch compared with the other rhynchonellide, Eohemithiris, the difference in relative rates is not significant $(P>0.08)$. Similarly, Glottidia is on a longer branch than Lingula, but the rate difference is borderline $(P=0.049)$. The overall pattern (Fig. 2) shows that inarticulate brachiopods and phoronids are generally slower-evolving than articulated brachiopods, with craniids being the slowest of all.

Parsimony heuristic searches of all 3275 sites of the SSU + LSU alignment gave one MPT $(L=1261$, $\mathrm{CI}=0.68, \mathrm{RI}=0.60$ ) in which the chiton was in its expected position as sister to the ingroup, and phoronids were the sister-group of inarticulates (with $76 \%$ bootstrap support). When uninformative sites were excluded (leaving 377 informative characters) base composition was homogeneous $(P=0.67)$ and there was ample nonrandom structure, $\mathrm{PTP}=0.01$. Parsimony $\mathrm{B} \& \mathrm{~B}$ search found a single MPT $(L=973, \mathrm{CI}=0.59, \mathrm{RI}=0.60)$ in which the topology was unchanged (as expected) and bootstrap support for the (phoronid + inarticulate) clade rose to $83 \%$. In both sets of analyses the discinid and lingulid indicator clades were correctly resolved as sisters ( $\sim 55 \%$ support), but both expected articulate brachiopod clades were not recovered, suggesting that despite being guaranteed to find the shortest tree, parsimony analyses may be sub-optimal.

The strength of evidence that phoronids belong within brachiopods as the sister-group of inarticulate brachiopods was further assessed by decay analyses. When B\&B parsimony trees successively longer than the minimal tree were saved, phoronids remained as sister-group of inarticulates until six steps had been added, at which point resolution of brachiopods and phoronids was reduced to a trichotomy. With the addition of two more steps the tree collapsed further, with phoronids as sister to all brachiopods. Analyses based on Bremer support execution files prepared in MacClade confirmed these decay values. In another test, MacClade was used to construct a constraint tree in which phoronids were placed between the chiton and pectinid outgroups, and hence unrelated to brachiopods. This tree was 23 steps longer than the MPT.

In view of the failure of parsimony analyses to recover all a priori indicator clades, attention was focused on ML analyses, in which preliminary analyses (not shown) had been more promising.

\section{Maximum likelihood analyses}

In Modeltest the hLRT criterion identified $\operatorname{TrN}+\mathrm{I}+\mathrm{G}$, and AIC identified TIM $+\mathrm{I}+\mathrm{G}$, as (similar) best-fitting models for the 14-taxon, 3275-site alignment. The ML trees found with these models differed slightly in likelihood (hLRT- $\ln L$ 11105.67;
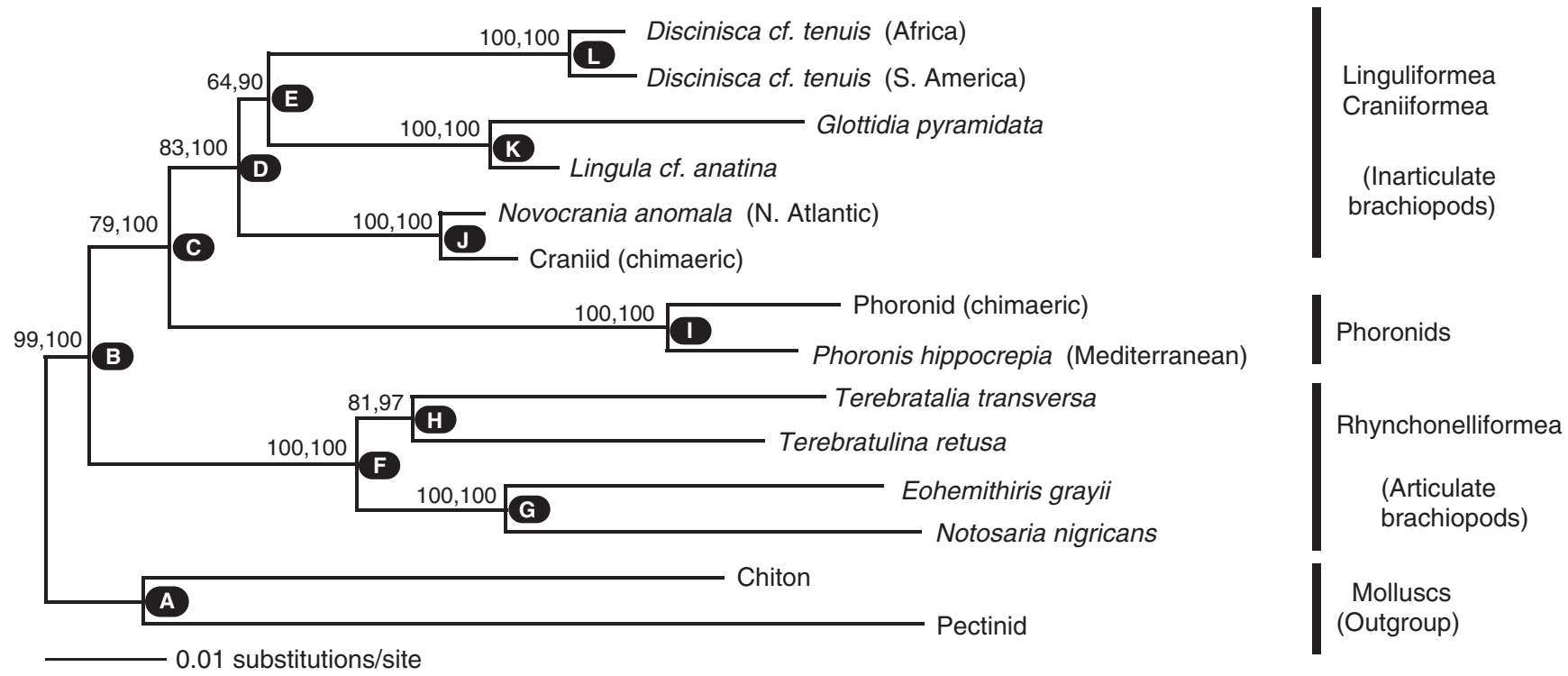

Fig. 2. Phoronid and brachiopod phylogeny. Maximum likelihood heuristic search and bootstrap analysis of 3275 sites of concatenated SSU + LSU alignment. The AIC-selected model used empirical base frequencies with 6 rates (A-C, A-T, C-G and G$\mathrm{T}=1.0000 ; \mathrm{A}-\mathrm{G}=2.1485$; $\mathrm{C}-\mathrm{T}=4.6974$; proportion of invariant sites $=0.6171$; gamma distribution shape parameter $=0.6141$ ). Heuristic search with TBR branch exchange found one tree, $-\ln L 11079.107$, and the bootstrap consensus showed the same topology. Support values (\%) are: first, bootstrap proportions from heuristic ML search of 500 pseudoreplicates; second, Bayesian consensus clade support from analysis with the $6 \mathrm{st}+\mathrm{I}+\mathrm{G}$ model. With the autocorrelated gamma model all nodes received $99-100 \%$ support. Node labels correspond to entries in Table 2. 
AIC $-\ln L 11079.11)$ but did not differ in topology or bootstrap support. The AIC tree is shown in Fig. 2. Thus, ML analyses give the same estimate of (phoronid + brachiopod) relationships as parsimony - phoronids are the sister-group of inarticulate brachiopods, with $\sim 80 \%$ bootstrap support. In these ML trees all brachiopod indicator clades were recovered, suggesting that ML analysis is nearer optimal than parsimony. When trees were compared, S-H tests did not exclude one in which phoronids were constrained to be sister to all brachiopods $(P=0.18)$, but did exclude $(P<0.05)$ trees in which the (phoronid + brachiopod) clade was absent. Thus, ML tree comparisons and parsimony decay analyses gave similar results - the (phoronid + brachiopod) clade is strongly supported; the (phoronid + inarticulate brachiopod) clade appears in optimal trees with good support, and relationships that do not closely associate phoronids with brachiopods are firmly rejected.

\section{Bayesian maximum likelihood analyses}

Bayesian ML analyses using both simple and complex models on the 14-taxon, 3275-site alignment (pectinid and chiton outgroups) strongly confirmed the findings described above. The MrModeltest-selected model for both partitions was GTR $+\mathrm{I}+\mathrm{G}$ (AIC and hLRT criteria), i.e. six rates with proportion of invariant sites and gamma distribution estimated from the data. Applied to the SSU partition alone, this confirmed earlier weak support for a (phoronid + craniid) clade, as did the better-fitting autocorrelated gamma model (not included in MrModeltest). Applied to the LSU partition alone and to both partitions, GTR $+\mathrm{I}+\mathrm{G}$ confirmed the ML tree shown in Fig. 2. Again, the autocorrelated gamma model fitted the data better than GTR $+\mathrm{I}+\mathrm{G}$, and six rates were better than two (hLRT, $P<0.01$ ). With the best-fitting model $10^{6}$ generations gave a nonsignificantly higher likelihood than $10^{5}$ generations $(P>0.05)$, and adding the covarion model caused only a minor improvement $(P>0.05)$. In all analyses with 6 rates the $95 \%$ credible set contained 2 or 3 trees in which all nodes had very high clade support (91-100\%), and phoronids were the sister-group of inarticulate brachiopods $(98-100 \%)$. With the best-fitting model (autocorrelated gamma) all clades had $99-100 \%$ support. The brachiopod indicator clades were correctly resolved in all analyses, with strong support. The same topology and support levels were found in the consensus of all (600 or 9600) post-burnin trees as in the $95 \%$ credible set.

When the GTR $+\mathrm{I}+\mathrm{G}$ model was used on the complete 18-taxon alignment (crinoid outgroup, details not shown), Bayesian analysis gave $>90 \%$ support for the (phoronid + inarticulate brachiopod) clade and correct resolution of both brachiopod indicator clades. In the consensus of all post-burnin trees the pectinid and chiton formed an unresolved (lophotrochozoan) trichot- omy with the articulate brachiopod and the (phoronid + inarticulate brachiopod) clades. Thus, even when all the distant outgroups were included, Bayesian analyses strongly confirmed the sister-group relationship of (phoronids + inarticulate brachiopods).

\section{Analysis of the excluded sites}

Parsimony analyses of the data excluded from the concatenated SSU+LSU alignment by Gblocks as potentially misaligned (645 sites, of which 345 were parsimony-informative) gave mixed results. Heuristic search of the 18-taxon alignment (all sites, crinoid outgroup) gave one MPT $(L=1754, \quad \mathrm{CI}=0.53$, $\mathrm{RI}=0.40$, not shown) in which the various outgroups were correctly resolved, but phoronids appeared as the sister of lingulid inarticulates and neither of the brachiopod indicator clades was correct. Bootstrap analysis revealed that signal was weak; the only group with $>50 \%$ support comprised all the slow-evolving taxa (brachiopods, phoronids, chiton and pectinid, $56 \%$ ). When the four more distant outgroups were excluded and the pectinid used as outgroup, the result was similar, with phoronids and lingulids as sister-taxa $(53 \%)$, but the chiton was now outside the (brachiopod + phoronid) clade, which had $93 \%$ support. However, not only were the indicator clades of articulate brachiopods incorrectly resolved, but also articulates appeared as the sister-group of discinids (58\% support), a morphologically nonsensical result. Thus, the sequence excluded by Gblocks contained unreliable phylogenetic signal.

\section{Molecular clock and palaeontological age-calibration analyses}

As expected from the relative rate tests, likelihood ratio tests of tree-scores excluded clock-like behaviour in the 14-taxon, SSU + LSU alignment $(P<0.01)$. Therefore, node depths for time calibration were estimated from rate-smoothed, ultrametric trees (chronograms) prepared from no-clock ML trees using both NPRS and PL algorithms implemented in r8s, with recommended settings. There were only small, unsystematic differences between algorithms, and a representative NPRS chronogram is shown in Fig. 3a. In these trees, confidence intervals $(95 \%)$ on the three deepest nodes were about $\pm 1 \%$ in one case and did not differ from the reported values in two cases. Thus, by this calculation method, node depths were apparently estimated in r8s with little error. Details of the palaeontological time calibration of the rate-smoothed tree of Fig. $3 \mathrm{a}$ are given in Table 2 and Figs. $3 b$ and 3c, based on index fossils chosen (with advice) from the palaeontological literature before the regression analysis was performed. Linear regression analyses of node depths and palaeontological ages used maximum, mean and minimum ages to represent uncertainties in the fossil record; such differences were 
small (Fig. 3b). In the palaeontological mean age regression (Fig. 3c, $r^{2}=0.92$ ), 3 of 9 data-points were just outside the $95 \%$ confidence intervals, but no points were close to or outside the $95 \%$ prediction intervals. The normal plot of residuals was almost linear, and there was no clear trend of residuals versus fits (not shown). This regression $(y=705.61 x-22.66)$ dates the node representing genetic divergence between the

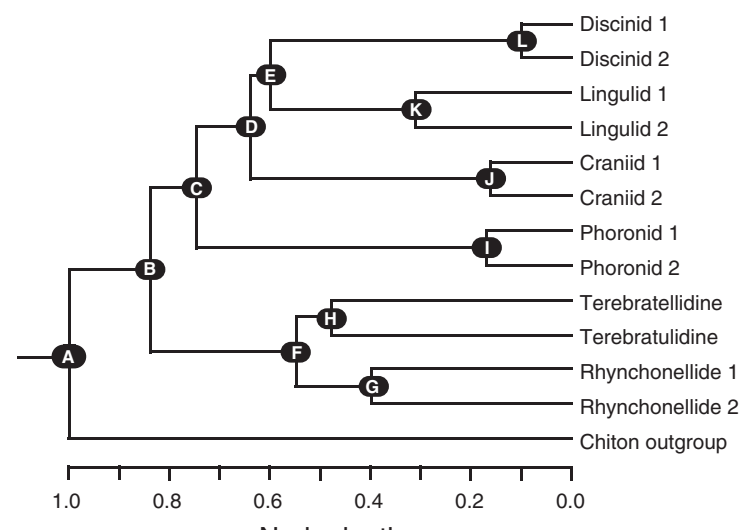

(a)
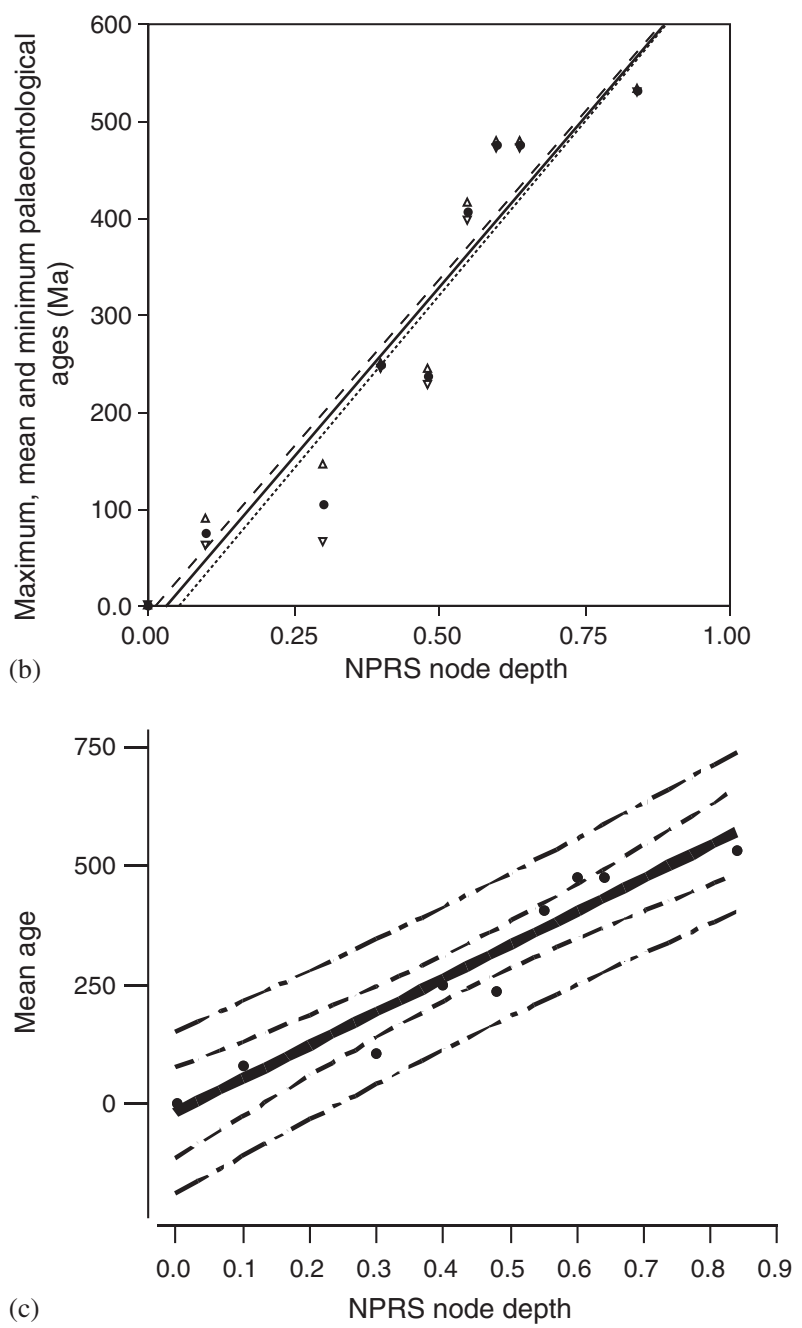

common ancestor of the chiton (Mollusca: Polyplacophora) and the (brachiopods + phoronids) clade at $\sim 683 \mathrm{Ma}$ (Table 2), and in most cases gives reasonable agreement $( \pm 50 \mathrm{My}$ or less $)$ between predicted and geological ages (see Discussion).

In the absence of a sure and simple way to measure errors associated with the estimation of rate-smoothed node depths from individual ML trees, a novel approach was also explored, based upon Bayesian consensus trees with branch lengths. These trees are derived from the bipartitions in hundreds of fundamental trees, each the result of a random perturbation, and therefore are somewhat analogous to bootstrap consensus trees. Bayesian consensus trees derived from runs with a variety of parameter settings, and lying within a small $95 \%$ credible set, were used as input to $\mathrm{r} 8 \mathrm{~s}$, in which they were smoothed with both NPRS and PL methods and depths were obtained for every internal node $($ root $=1.00)$. Confidence intervals for node $\mathrm{B}$ ranged from $0.84 \pm 0.06$ to $0.84 \pm 0.00$. In every case, the correlation with mean palaeontological age differed only slightly from (was virtually superimposable on) that shown in Fig. 3b, and the regression equations predicted similar ages at node depth $=1.00$ (differences $1-2 \%)$. Thus, the choice of Bayesian ML model had only trivial effects on age calibration and confirmed the standard ML result. Although PL was more effective at rate-smoothing (ratios of minimum to maximum lineage rates in smoothed trees were NPRS, 1: 4.7; PL, 1: 1.001), PL node depths were slightly less well correlated with palaeontological age $\left(r^{2} \sim 0.85\right)$, and the worst-fitting data-points were slightly further outside the $95 \%$ confidence intervals. Thus, the various smoothing methods and ML models resulted in only marginal differences in estimated node depths (Table 2).

\section{Linearised versus rate-smoothed trees}

The removal of rate-discordant taxa was tested as an alternative to rate-smoothing. In a first test, the taxon

Fig. 3. Phoronid and brachiopod divergence-time calibration. (a) NPRS rate-smoothed ML chronogram with nodes labelled to correspond to entries in Table 2. Branch lengths proportional to node depth, node $\mathrm{A}=1.00$. (b) Linear regression of maximum, mean and minimum palaeontological ages on NPRS node depth (see Fig. 3a and Table 2 for details). Regression equations: maximum age (upward triangles, dashed line) $y=693.87 x-8.26, r^{2}=0.93$; mean age (circles, solid line) $y=705.61 x-22.66, r^{2}=0.92$; minimum age (downward triangles, dotted line) $y=717.35 x-37.06, r^{2}=0.90$. (c) Linear regression of mean palaeontological age on NPRS node depth, with $95 \%$ confidence and prediction intervals. Regression equation $y=705.61 x-22.66, \quad r^{2}=0.92$. Datapoints $=$ filled circles, regression $=$ solid line, $95 \%$ confidence intervals $=$ dashed lines, $95 \%$ prediction intervals $=$ long-andshort dashed lines. 
set was pruned by removal of the four articulate brachiopods, the more distant outgroups and the longer-branched lingulid (Glottidia), leaving three significant rate differences $(P<0.05)$ : craniids slower than discinids (ratio 1:1.09), craniids slower than phoronids (1:1.76), and lingulid slower than phoronids (1:1.45). Parsimony and ML tree-searches and bootstrap analyses (using models and parameters re-estimated by Modeltest from all-sites and variable sites data) were repeated, with no change in tree topology but with increased support for the (phoronid + inarticulate brachiopod) node (not shown). The resulting ML trees were smoothed using NPRS in r8s. This data set did not include enough points for a full regression analysis, and the ages of the resulting nodes were estimated as before. In each case, differences were small and in worse agreement with palaeontological age, being $\sim 15$ to $\sim 50$ My younger, indicating that inclusion of fastevolving (long-branched) taxa tends to increase node depths.

In a second test, all remaining significant rate differences $(P<0.05)$ were eliminated by reducing the taxon set to the two discinids (representing inarticulate brachiopods), the two phoronids, and the chiton and pectinid outgroups. The optimum ML model was reestimated for this minimal taxon set and used in exhaustive ML bootstrap searches, in which all 3 nodes received 99 or $100 \%$ support. After NPRS smoothing with root node depth $=1.00$, the discinid:phoronid node was reported at depth $=0.78$, hardly different from the values obtained in the presence of significant rate variations (0.75-0.77; Table 2, node C). As a further check on the effects of rate variation, this rate-uniform data set was analysed by exhaustive ML search in PAUP* with the molecular clock enforced. In the resulting ultrametric tree (pectinid outgroup) the discinid:phoronid node was at 0.81 relative to the chiton $=1.00$. Thus, rate-smoothing caused a slight reduction in the estimated age of divergence between brachiopods and phoronids, but even significant rate variation between lineages scarcely affected the estimated relative time depths of the brachiopod:chiton and inarticulate brachiopod:phoronid nodes.

\section{Quartet analysis}

A quartet method for time calibration (Rambaut and Bromham 1998) was applied to three deep nodes, one estimate being made with two different quartets. In each case the estimated node age was impossibly young, $\sim 100$ to $\sim 150$ My younger than indicated by the fossil record (Table 2). A similar outcome has been reported (Brochu 2004), and the method was not further explored.

\section{Discussion}

As previously found with data from the SSU rDNA gene (Cohen and Gawthrop 1996), the sequence of brachiopod clade origins in the SSU + LSU gene tree agrees with the stratigraphic order of first appearances. Thus, the molecular data and analyses reported here pass a fundamental test of validity and merit further discussion, for which the labelled nodes in Figs. 2 and 3, and the support values in Fig. 2, provide necessary points of reference.

The branch from node A to node B tells us that extant brachiopods (including phoronids) are unambiguously monophyletic with respect to molluscan (and in effect all other protostome) outgroups. Monophyly clearly excludes hypotheses in which the brachiopod-like body plan originated separately in lineages leading to Linguliformea and (Rhynchonelliformea + Craniiformea), respectively (e.g. Li and Xiao 2004, and references therein).

The dichotomy at node B shows an early split between the ancestors of extant articulate (rhynchonelliform) and inarticulate (linguliform and craniiform) brachiopods plus phoronids. Consistent with this, the fossil record shows approximately coeval, Tommotian (Lower Cambrian, 534-530 Ma) forms assigned to these taxa (Table 2). The common ancestor represented by node B, by cladistic parsimony, should have possessed all the brachiopod-defining synapomorphies that are common to both descendant lineages: lophophore; recurved gut; embryological metamorphosis with some form of mantle reversal; bivalve shell secreted by a uniquely organised ectodermal, epithelial fold; pedicle and related shell features; marginal setae; sessile habit; etc. However, because the phoronid tube is unmineralised, and because the ontogenetically earliest 'shell' in both Palaeozoic and extant lingulids and discinids is unmineralised organic polymer (Yatsu 1902; Cusack et al. 1999), it is possible that inarticulate brachiopods with a well-mineralised shell did not evolve before node D. If so, this node must represent a time earlier than the Lower Cambrian (Atdabanian, 530-524 Ma) Chengjiang fauna, among which the inarticulate brachiopod, Diandongia, was well mineralised (Xian-Guang et al. 2004). The alternative is that a mineralised shell was present at node $\mathrm{C}$, but was lost between $\mathrm{C}$ and $\mathrm{I}$, during the evolution of phoronids. The latter would allow for a single origin of mineralisation (but not a single origin of mineralisation style) at or before node $\mathrm{B}$, and would place this node no later than the Atdabanian.

Phoronids appear to have originated from the urinarticulate brachiopod represented by node $\mathrm{C}$, through the loss of brachiopod apomorphies or their transformation into phoronid ones: chitinous tube secreted by a mantle collar; actinotroch-style larva; and, probably, metamorphosis with evagination from a metasomal 
pouch. All four lineages descending from node C primitively share (or shared) planktotrophic larvae (Freeman and Lundelius 1999) and important features of early ontogeny (see details and discussion in Freeman 2000). The conclusion that phoronids are the sistergroup of the three extant inarticulate brachiopod lineages, i.e. craniids, discinids, and lingulids, therefore seems likely to endure, unless strongly contradictory genomic evidence emerges from other sources or through alternative analyses of existing data. Its main implication for Linnean taxonomy was foreseen, as follows: "if it later becomes clear that phoronids and inarticulate brachiopods ... really are closely related, this could be recognised by designating phoronids as a class (e.g. 'Phoronata') in the subphylum Linguliformea" (Cohen 2000, p. 229). That suggestion is formalised below (see Proposed new classification), along with the reduction of Craniiformea to a class, 'Craniata', within the Linguliformea.

Branch $\mathrm{C}-\mathrm{D}$ then represents the divergence of inarticulate brachiopods from phoronids, and if the common ancestor with phoronids was not mineralised this involved the onset of mineral reinforcement of the organic 'shell'. In branch D-J, this reinforcement was by calcite (Williams and Wright 1970), and this branch also led to a number of wholly extinct clades, as well as to the extant, cemented, pedicle-less craniids. In branch D-E, by contrast, reinforcement was by apatite, leading to various wholly extinct lineages (e.g. Paterinates) and eventually to the extant lingulids and discinids, whose main similarities are noted above.

Node D represents a clade containing both calcitic craniiforms and apatitic linguliforms. It is well supported and was previously reported by Carlson (1995) on the basis of a cladistic analysis of morphological characters. This suggests that the current treatment of craniiforms as a separate subphylum (Williams et al. 1996) is unjustified; they would be better regarded as a class, equivalent in rank to phoronids and lingulates. The cladistic basis for the subphylum rank of craniiforms may have been mainly that carbonate (calcitic) mineralisation in craniiforms and rhynchonelliforms was coded as a single character state, the different microfabrics being coded separately (Williams et al. 1996). It may also have had an historical component (Gorjansky and Popov 1986; Popov et al. 1993). However, independent origins of calcitic mineralisation in craniate and rhynchonellate brachiopods are consistent with, and suggested by, their differing mineral growth regimes and micro-fabrics (Williams 1997). It has recently been suggested that massive mineralisation in other taxa also arose polyphyletically, being favoured for biomechanical reasons, rather than as armour against predation (Cohen 2005).

The rhynchonelliform branch B-F and below needs little discussion. At or immediately after B, and well before $\mathrm{F}$, all the characteristic synapomorphies of articulate brachiopods would have evolved, including formation of a multilayered calcitic-organic composite shell with a mineralised hinge and associated diductoradductor muscle system, etc. As in the inarticulate branch, various wholly extinct lineages also diverged from this stem, and it is not clear from which basal element extant rhynchonelliforms descend.

Disagreements between the fossil record and the gene tree hinge on the relative and absolute times of lineage origins (Table 2). Timing of evolutionary events in the fossil record is subject to errors due to actual gaps in deposition, apparent gaps that may be bridged by future fossil finds, errors of interpretation arising from the imperfect preservation or lack of internal or external detail of specimens, as well as - particular problems with brachiopods - lack of enough morphological characters, and convergence. Moreover, the earliest fossil appearance of any taxon postdates its genetic origin. Similarly, the timing of divergence events inferred from a gene tree is subject to error, being based upon extrapolation from a (smoothed) global molecular clock in data, most of which (here) failed a formal test for lineage-specific rate uniformity, and upon regression analysis. Regression necessarily merges a suite of data-points into a single, mathematical relationship, and this may itself be a source of error, especially as hierarchical tree nodes are not truly independent. The real errors associated with these various estimation methods are uncertain, but appear to be approximately $\pm 0.06 \% \quad(\sim 50 \mathrm{My}$, smoothed clock) and $\pm 50 \mathrm{My}$ or more (regression). In addition, although in the present data homoplasy (seen as saturation) is slight, it may result in deep divergencetime estimates being artificially late, even when derived from ML distances based upon a selected evolutionary model. Thus, disagreements between palaeontological and genetic ages of $\sim 50 \mathrm{My}$ will be assumed to fall within the various error ranges.

There are, in fact, only three cases in which the palaeontological and genetic ages differ by more than $50 \mathrm{My}$ (Table 2). At node $\mathrm{E}$, the genetic age is $\sim 75 \mathrm{My}$ younger than the fossil age. This might be accounted for by the slow rate of molecular evolution in the discinid lineage, but this disagreement is not fully explained, and would be worse if the Zhanatellidae, which share some characteristics with discinids and appeared in the late Atdabanian (Holmer and Popov 2000), are more appropriate index fossils. At node $\mathrm{G}$, the genetic age is $\sim 80 \mathrm{My}$ older than the palaeontological age. If not caused by the expected lag between genetic divergence and the first appearance of fossils, this could be due to the first author's (in this case) unguided choice of index taxon (family, superfamily, etc.), and/or to the relatively fast evolutionary rate of one of the rhynchonellide terminal taxa, or uncertain evolutionary relationships among fossil rhynchonellides. At node $\mathrm{K}$, the genetic 
age is $\sim 85$ My older than the fossil age, a difference that is again in the expected direction and could be resolved by range extension of Glottidia-like fossils and/or be explained by the relatively fast evolution of Glottidia compared with Lingula. Thus, possible explanations exist for two of the three cases in which genetic and palaeontological ages differ by more than the likely estimation error, suggesting that the regression analysis is reasonably well founded. Moreover, genetic age estimates were scarcely affected by significant betweentaxon differences in molecular evolution rate.

How much confidence should be placed in our results? Clearly the two data partitions disagree superficially: both support a (phoronid + brachiopod) clade, but only LSU and the combined partitions give strong support to a sister-group relationship between phoronids and inarticulates; with SSU alone, the sister-group forms (with weak support) only with the closest inarticulate (craniid) lineage, not with the more distant lingulids and discinids. This difference, and the lack of conflict in the ILD test and in network analysis, together suggest that this reflects lack of signal in SSU rather than true conflict between partitions, consistent with the many fewer informative sites SSU provides. Thus, so long as the rRNA genes are themselves reliable sources (as from overall metazoan phylogeny they appear to be) the relationships inferred from the SSU + LSU alignment seem to be well established. For the palaeontologically age-calibrated tree, in the absence of statistically relevant and valid confidence limits, perhaps the best indication of reliability comes from the fact that both here and in previous reports based on less sophisticated analysis of SSU sequences alone (Cohen and Gawthrop 1996, 1997; Cohen et al. 1998a), the recovered brachiopod inter-relationships are generally congruent with those independently inferred from morphology, stratigraphy and biogeography (vide the distinctness of New Zealand's endemic terebratellides). To test the results against such complex facts may be more satisfactory than to calculate very wide confidence limits with a sophisticated mathematical model but using data that probably lack resolving power (e.g., an extreme case, Cutler 2000). Despite the apparent reliability and robustness of the results, there remain potential and fundamental problems with available methods of phylogenetic inference (Kolaczkowski and Thornton 2004) which caution us to remember that conclusions like those presented here are but hypotheses, open to refutation.

If their main conclusions and potential error-ranges are taken at face value, the present analyses lend weight to the proposition (e.g. Wray et al. 1996) that the radiation of the metazoan phyla began well before the Cambrian. Regression analysis based on node depths in the smoothed tree places genetic divergence between molluscs (represented by the chiton outgroup) and the (brachiopod + phoronid) clade at $\sim 685 \mathrm{Ma}$, with confidence intervals (extrapolated to node depth $=1.00$ ) that span $\sim 560$ to $\sim 900 \mathrm{Ma}$ (a similar estimate, ca. 600-900 Ma, was obtained with simpler methodology using SSU sequences from many more brachiopods; Cohen et al. 1998a.). This range contrasts with the first appearance of macroscopic, metazoan fossils in the Lower Cambrian, the base of which is now dated to $542 \mathrm{Ma}$. Thus, unless the age of the brachiopod-chiton divergence is greatly over-estimated (saturation effects would tend towards underestimation), the considerable molecular evolutionary distance between more basal metazoans (e.g. the deuterostome and other protostome outgroups employed here) pushes the main divergence of metazoan phyla even further back in time, favouring the evolution of geologically 'hidden' (presumably planktonic, unmineralised) metazoans in the Proterozoic. This conclusion could, perhaps, be avoided if average rates of metazoan molecular evolution in the Late Proterozoic or Early Cambrian were episodically much faster than during the remainder of the Phanerozoic, but a simulation study (Levinton et al. 2004) suggests that this is not a realistic explanation. Thus, it seems almost inescapable that major genetic and morphological divergence of metazoans took place well before the first appearance in the Lower Cambrian (Tommotian, 534-530 Ma) of articulate and inarticulate brachiopod fossils.

Unlike molluscs arthropods and annelids, which are the other richly diverse lophotrochozoan phyla, brachiopods combine extant lineages of Early Cambrian origin, clear inter-relationships and an excellent fossil record with morphological simplicity and conservatism, and generally low rates of molecular evolution. This suggests that well-selected brachiopods offer an excellent opportunity to glimpse or reconstruct the ancestral lophotrochozoan genome, and that complete or comparative genomic sequencing (Blakesley et al. 2004) of one or more brachiopod genomes should have quite high priority. If so, the choice should fall first on a craniid and a discinid, possibly also a phoronid, rhynchonellid and terebratulid, but not on a lingulid because their infaunal habit is atypical and derived.

\section{Proposed new classification}

On the basis of the SSU rDNA evidence, three names have been proposed for a phylum that unites phoronids and brachiopods (Cavalier-Smith 1998; Zrzavy et al. 1998; Cohen 2000). Only one of these proposals (Cohen 2000) took account (somewhat uncomfortably, as noted by Peterson and Eernisse 2001) of the new high-level brachiopod classification (Williams et al. 1996) and of concurrent revision of the main source-book for brachiopod biology (Kaesler 1997-2002 and in press). 
In this proposal, phoronids were treated as a subphylum (Phoroniformea) within the Brachiopoda, but it was recognised that further data might justify class rather than subphylum rank. In light of the new evidence presented here, the latter classification is adopted. This solution, which assumes a fundamental homology of the brachiopod and phoronid body plans (Cohen et al. 2003), will cause less disturbance (especially in palaeontology) than the erection of a completely new phylum. Also, given the molecular results reported here, a further modification of the current high-level classification is called for, reducing the subphylum Craniiformea to a class, 'Craniata', so that phoronids, craniids, and lingulids + discinids comprise three classes (Phoronata, Craniata and Lingulata) within the subphylum Linguliformea.

\section{Diagnoses}

Diagnoses of extant subphyla and classes as in Williams et al. (1996) unless otherwise stated, modified to include phoronids.

\author{
Phylum Brachiopoda Duméril, 1806 \\ Diagnosis as in Cohen (2000), modified from Emig \\ (1977b, 1982). \\ Subphylum Linguliformea Williams et al., 1996 \\ Diagnosis as in Williams et al. (1996), with \\ emendation "or in a cylindrical tube of their own \\ secretion" (after Emig 1982). \\ Class Craniata Williams et al., 1996 \\ Diagnosis as for subphylum Craniiformea and \\ Class Craniata in Williams et al. (1996). \\ Class Phoronata cl. nov. \\ Diagnosis as for subphylum Phoroniformea in \\ Cohen (2000). \\ Class Lingulata Gorjansky \& Popov, 1985 \\ Diagnosis as in Williams et al. (1996). \\ Subphylum Rhynchonelliformea Williams et al., 1996 \\ Class Rhynchonellata Williams et al., 1996 \\ Order Rhynchonellida Kuhn, 1949 \\ Order Terebratulida Waagen, 1883 \\ Order Thecideida Elliot, 1958
}

\section{Acknowledgements and dedication}

AW's stay in Glasgow was made possible by an Erasmus-Socrates scholarship. Sequencing costs were met by funds made available by the Dean of the Faculty of Biomedical and Life Sciences. We thank Julie Galbraith and other members of the IBLS sequencing unit for their skilled work. Gonzalo Giribet (Harvard University) provided tissue of Acanthopleura granulatum. DNA of Glottidia pyramidata was a gift from Ken
Halanych, Auburn University. Access to a test version of PAUP*4 was facilitated by J. Wilgenbusch, University of South Florida. We acknowledge the generosity of the many people who collected brachiopods and phoronids or donated specimens, and are grateful for advice received from S.J. Carlson, University of California, Davis; L. Holmer, University of Uppsala, Sweden; S.L. Long, The Natural History Museum, London; R.H. Wilson and R. Page, University of Glasgow. Two anonymous referees provided helpful comments and suggestions, and Jon Mallatt (Washington State University, Pullman) provided materials, invaluable advice on LSU rDNA amplification and sequencing, and helpful, detailed criticism of the manuscript.

This paper is dedicated to the memory of the late doyen of brachiopod studies, Alwyn Williams (1921-2004).

\section{References}

Abouheif, E., Zardoya, R., Meyer, A., 1998. Limitations of metazoan 18S rRNA sequence data: implications for reconstructing a phylogeny of the animal kingdom and inferring the reality of the Cambrian explosion. J. Mol. Evol. 47, 394-405.

Adoutte, A., Philippe, H., 1993. The major lines of metazoan evolution: summary of traditional evidence and lessons from ribosomal RNA sequence analysis. In: Pichon, Y. (Ed.), Comparative Molecular Neurobiology. Birkhäuser, Basel, pp. 1-30.

Ajuh, P.M., Heeney, P.A., Maden, B.E., 1991. Xenopus borealis and Xenopus laevis $28 \mathrm{~S}$ ribosomal DNA and the complete 40S ribosomal precursor RNA coding units of both species. Proc. R. Soc. London B 245, 65-71.

Blakesley, R.W., Hansen, N.F., Mullikin, J.C., Thomas, P.J., McDowell, J.C., Maskeri, B., Young, A.C., Benjamin, B., Brooks, S.Y., Coleman, B.I., Gupta, J., Ho, S.-L., Karlins, E.M., Maduro, Q.L., Stantripop, S., Tsurgeon, C., Vogt, J.L., Walker, M.A., Masiello, C.A., Guan, X., Bouffard, G.G., Green, E.D., 2004. An intermediate grade of finished genomic sequence suitable for comparative analyses. Genome Res. 14, 2235-2244.

Brochu, C., 2004. Calibration age and quartet divergence date estimation. Evolution 58, 1375-1382.

Carlson, S.J., 1990. Phylogenetic relationships among brachiopod higher taxa. In: McKinnon, D.I., Lee, D.E., Campbell, J.D. (Eds.), Brachiopods through Time. Balkema, Rotterdam, pp. 3-10.

Carlson, S.J., 1995. Phylogenetic relationships amongst brachiopods. Cladistics 11, 131-197.

Carlson, S.J., Leighton, L.R., 2001. The phylogeny and classification of Rhynchonelliformea. In: Carlson, S.J., Sandy, M.R. (Eds.), Brachiopods Ancient and Modern. A tribute to G. Arthur Cooper, vol. 7. Paleontol. Soc. Pap., Pittsburgh, pp. 27-51. 
Castresana, J., 2000. Selection of conserved blocks from multiple alignments for their use in phylogenetic analysis. Mol. Biol. Evol. 17, 540-552.

Cavalier-Smith, T., 1998. A revised six-kingdom system of life. Biol. Rev. 73, 203-266.

Cavalier-Smith, T., Allsopp, M.T.E.P., Chao, E.E., BouryEsnault, N., Vacelet, J., 1996. Sponge phylogeny, animal monophyly, and the origin of the nervous system: $18 \mathrm{~S}$ rRNA evidence. Can. J. Zool. 74, 2031-2045.

Chen, J., Zhou, G., 1997. Biology of the Chengjiang fauna. Bull. Natl. Mus. Sci. 10, 11-105.

Cohen, B.L., 2000. Monophyly of brachiopods and phoronids: reconciliation of molecular evidence with Linnaean classification (the subphylum Phoroniformea nov). Proc. R. Soc. London B 267, 225-231.

Cohen, B.L., 2001. Genetics and molecular systematics of brachiopods. In: Carlson, S.J., Sandy, M.R. (Eds.), Brachiopods Ancient and Modern. A tribute to G. Arthur Cooper, Vol. 7. Paleontol. Soc. Pap., Pittsburgh, pp. 53-67.

Cohen, B.L., 2005. Not armour, but biomechanics, ecological opportunity and increased fecundity as keys to the origin and expansion of the mineralised benthic metazoan fauna. Biol. J. Linn. Soc. 85, 483-490.

Cohen, B.L., Gawthrop, A.B., 1996. Brachiopod molecular phylogeny. In: Copper, P., Jin, J. (Eds.), Brachiopods: Proceedings of the Third International Brachiopod Congress, Sudbury, Ontario, 1995. Balkema, Rotterdam, pp. 73-80.

Cohen, B.L., Gawthrop, A.B., 1997. The brachiopod genome. In: Kaesler, R.L. (Ed.), Treatise on Invertebrate Paleontology, Part H1, Brachiopoda, revised. Geological Society of America and University of Kansas, Boulder, Colorado and Lawrence, Kansas, pp. 189-211.

Cohen, B.L., Gawthrop, A.B., Cavalier-Smith, T., 1998a. Molecular phylogeny of brachiopods and phoronids based on nuclear-encoded small subunit ribosomal RNA gene sequences. Phil. Trans. R. Soc. B 353, 2039-2061.

Cohen, B.L., Stark, S., Gawthrop, A.B., Burke, M.E., Thayer, C.W., 1998b. Comparison of articulate brachiopod nuclear and mitochondrial gene trees leads to a clade-based redefinition of protostomes (Protostomozoa) and deuterostomes (Deuterostomozoa). Proc. R. Soc. London B 265, 475-482.

Cohen, B.L., Holmer, L.E., Lüter, C., 2003. The brachiopod fold: a neglected body plan hypothesis. Palaeontology 46, 59-65.

Cohen, B.L., Améziane, N., Eléaume, M., Richer de Forges, B., 2004. Crinoid phylogeny: a preliminary analysis (Echinodermata: Crinoidea). Mar. Biol. 144, 605-617.

Cusack, M., Williams, A., Buckman, J.O., 1999. Chemicostructural evolution of linguloid brachiopod shells. Palaeontology 42, 799-840.

Cutler, D.J., 2000. Estimating divergence times in the presence of an overdispersed molecular clock. Mol. Biol. Evol. 17, $1647-1660$.

Emig, C.C., 1977a. Embryology of Phoronida. Am. Zool. 17, 21-37.

Emig, C.C., 1977b. Un nouvel embranchement: les Lophophorates. Bull. Soc. Zool. Fr. 102, 341-344.

Emig, C.C., 1979. British and other phoronids. In: Kermack, D.M., Barnes, R.S.K. (Eds.), Synopses of the British Fauna (New Series) 13. Academic Press, London, pp. 1-57.
Emig, C.C., 1982. The biology of Phoronida. Adv. Mar. Biol. 19, 1-89.

Fenton, M.A., Fenton, C.L., 1934. Scolithus as a fossil phoronid. Pan-Am. Geol. 61, 341-348.

Freeman, G., 2000. Regional specification during embryogenesis in the craniiform brachiopod Crania anomala. Dev. Biol. 22, 219-238.

Freeman, G., Lundelius, J.W., 1999. Changes in the timing of mantle formation and larval life history traits in linguliform and craniiform brachiopods. Lethaia 32, 197-217.

Gilbert, D., 1993. SeqApp. Computer program available by FTP from Molecular Biology Software Archive. University of Indiana, Bloomington.

Gorjansky, W.J., Popov, L.Y., 1986. On the origin and systematic position of the calcareous-shelled inarticulate brachiopods. Lethaia 19, 233-240.

Gradstein, F.M., Ogg, J.G., 2004. Geologic time scale. Lethaia 37, 175-181.

Gradstein, F.M., Ogg, J.G., Smith, A.G., 37 others, 2004. A Geologic Time Scale, 2004. Cambridge University Press, Cambridge.

Halanych, K., 1995. The phylogenetic position of the pterobranch hemichordates based on 18S rDNA sequence data. Mol. Phylog. Evol. 4, 72-76.

Halanych, K.M., Bacheller, J.D., Aguinaldo, A.M.A., Liva, S.M., Hillis, D.M., Lake, J.A., 1995. Evidence from 18S ribosomal DNA that the lophophorates are protostome animals. Science 267, 1641-1643.

Halanych, K.M., Bacheller, J.D., Aguinaldo, A.M.A., Liva, S.M., Hillis, D.M., Lake, J.A., 1996. Lophophorate phylogeny. Science 272, 283.

Hatschek, B., 1888. Lehrbuch der Zooogie. Gustav Fischer, Jena.

Helfenbein, K., 2000. Phoronids and articulate brachiopods: mitochondrial genomes, phylogeny and molecular evolution, abstract In: The Millenium Brachiopod Congress, London. Natural History Museum, London.

Helfenbein, K., Boore, J.L., 2003. The mitochondrial genome of Phoronis architecta - comparisons demonstrate that phoronids are lophotrochozoan protostomes. Mol. Biol. Evol. 21, 153-157.

Hendriks, L., Van Broeckhoven, C., Vandenberghe, A., van de Peer, Y., De Wachter, R., 1988. Primary and secondary structure of the $18 \mathrm{~S}$ ribosomal RNA of the bird spider Eurypelma californica and evolutionary relationships amongst eukaryotic phyla. Eur. J. Biochem. 177, 15-20.

Hillis, D.M., Dixon, M.T., 1991. Ribosomal DNA: molecular evolution and phylogenetic inference. Q. Rev. Biol. 66, 411-453.

Hillis, D.M., Moritz, C., Mable, B.K. (Eds.), 1996. Molecular Systematics. Sinauer Associates, Sunderland, MA.

Holmer, L.E., 2001. Phylogeny and classification: Linguliformea and Craniiformea. In: Carlson, S.J., Sandy, M.R. (Eds.), Brachiopods Ancient and Modern. A tribute to G. Arthur Cooper, vol. 7. Paleontol. Soc. Pap., Pittsburgh, pp. 11-26.

Holmer, L., Popov, L.E., 2000. Lingulida. In: Kaesler, R.L. (Ed.), Treatise on Invertebrate Paleontology, Part H2, Brachiopoda, revised. Geological Society of America and 
University of Kansas, Boulder, Colorado and Lawrence, Kansas, pp. 30-32.

Huson, D.H., 1998. SplitsTree: analysing and visualizing evolutionary data. Bioinformatics 14, 68-73.

Kaesler, R.L. (Ed.), 1997-2002 and in press. Treatise on Invertebrate Paleontology. Brachiopoda, Parts H1-6, revised. Geological Society of America and University of Kansas, Boulder, Colorado and Lawrence, Kansas.

Keightley, P.D., Johnson, T., 2004. MCALIGN: stochastic alignment of noncoding DNA sequences based on an evolutionary model of sequence evolution. Genome Res. 14, 442-450.

Kenchington, E.L.R.I., Naidu, K.S., Roddick, D.L., Cook, D.I., Zouros, E., 1993. Use of biochemical genetic markers to discriminate between adductor muscle of the sea scallop (Placopecten magellanicus) and the Iceland scallop (Chlamys islandica). Can. J. Fish. Aquat. Sci. 50, 1222-1228.

Kim, C.B., Moon, S.Y., Gelder, S.R., Kim, W., 1996. Phylogenetic relationships of annelids, molluscs and arthropods evidenced from molecules and morphology. Mol. Phylog. Evol. 6, 207-215.

Kolaczkowski, B., Thornton, J.W., 2004. Performance of maximum parsimony and likelihood phylogenetics when evolution is heterogeneous. Nature 431, 980-984.

Lee, D.E., MacKinnon, D.I., Smirnova, T.N., Baker, P.G., Boucot, A.J., Yu-Gan, J., Dong-Li, S., in press. Order Terebratulida, In: Kaesler, R.L. (Ed.), Treatise on Invertebrate Paleontology, Part H5, Brachiopoda, revised. Geological Society of America and University of Kansas, Boulder, Colorado and Lawrence, Kansas.

Levinton, J., Dubb, L., Wray, G.A., 2004. Simulations of evolutionary radiations and their application to understanding the probablility of a Cambrian explosion. J. Paleontol. 78, 31-38.

Li, G., Xiao, S., 2004. Tannuolina and Micrina (Tannuolinidae) from the Lower Cambrian of eastern Yunnan, south China, and their scleritome reconstruction. J. Paleontol. 78, 900-913.

Littlewood, D.T.J., Smith, A.B., Clough, K.A., Emson, R.H., 1997. The interrelationships of the echinoderm classes: morphological and molecular evidence. Biol. J. Linn. Soc. 61, 409-438.

MacKinnon, D.I., Biernat, G., 1970. The probable affinities of the trace fossil Diorygma atrypophilia. Lethaia 3, 163-172.

Maddison, D.R., Maddison, W.P., 2001. MacClade 4: Analysis of Phylogeny and Character Evolution. Sinauer Associates, Sunderland, MA.

Maddison, D.R., Swofford, D.L., Maddison, W.P., 1997. NEXUS: an extensible file format for systematic information. Syst. Biol. 46, 590-621.

Malia Jr., M.J., Lipscomb, D.L., Allard, M.W., 2003. The misleading effects of composite taxa in supermatrices. Mol. Phylog. Evol. 27, 522-527.

Mallatt, J., Winchell, C.J., 2002. Testing the new animal phylogeny: first use of combined large-subunit and smallsubunit rRNA gene sequences to classify the protostomes. Mol. Biol. Evol. 19, 289-301.

Mallatt, J.M., Garey, J.R., Schultz, J.W., 2004. Ecdysozoan phylogeny and Bayesian inference: first use of nearly complete $28 \mathrm{~S}$ and $18 \mathrm{~S}$ rRNA gene sequences to classify the arthropods and their kin. Mol. Phylog. Evol. 31, 178-191.

Manuel, M., Borchiellini, C., Alivon, E., Le Parco, Y., BouryEsnault, J.V., 2003. Phylogeny and evolution of calcareous sponges: monophyly of Calcinea and Calcaronea, high level of morphological homoplasy, and the primitive nature of axial symmetry. Syst. Biol. 52, 311-333.

Medina, M., Collins, A.G., Silberman, J.D., Sogin, M.L., 2001. Evaluating hypotheses of basal animal phylogeny using complete sequences of large and small subunit rRNA. PNAS (Washington) 98, 9707-9712.

Nylander, J., 2004. MrModeltest 2.0. Computer program distributed by the author. Evolutionary Biology Centre, Uppsala University.

Okusu, A., Schwabe, E., Eernisse, D.J., Giribet, G., 2003. Towards a phylogeny of chitons (Mollusca, Polyplacophora) based on a combined analysis of five molecular loci. Org. Divers. Evol. 4, 281-302.

Peterson, K., Eernisse, D.J., 2001. Animal phylogeny and the ancestry of bilaterians: inferences from morphology and 18S rDNA sequences. Evol. Dev. 3, 170-205.

Popov, L.E., Bassett, M.G., Holmer, L.E., Laurie, J., 1993. Phylogenetic analysis of higher taxa of Brachiopoda. Lethaia 26, 1-5.

Posada, D., 2001. Selecting the best-fit model of nucleotide substitution. Syst. Biol. 50, 580-601.

Posada, D., Buckley, T.R., 2004. Model selection and model averaging in phylogenetics: advantages of Aikake information criterion and Bayesian approaches over likelihood ratio tests. Syst. Biol. 53, 793-808.

Posada, D., Crandall, K.P., 1998. MODELTEST: testing the model of DNA substitution. Bioinformatics 14, 817-818.

Rambaut, A., Bromham, L., 1998. Estimating divergence dates from molecular sequences. Mol. Biol. Evol. 15, 442-448.

Rice, E.L., 1990. Nucleotide sequence of the $18 \mathrm{~S}$ ribosomal RNA gene from the Atlantic sea scallop Placopecten magellanicus (Gmelin, 1791). Nucleic Acids Res. 18, 5551.

Robinson, M., Gouy, M., Gautier, C., Mouchiroud, D., 1998. Sensitivity of the relative-rate test to taxonomic sampling. Mol. Biol. Evol. 15, 1091-1098.

Ronquist, F.R., Huelsenbeck, J.P., 2003. MrBayes 3: Bayesian phylogenetic inference under mixed models. Bioinformatics 19, 1572-1574.

de Rosa, R., Grenier, J.K., Andreeva, T., Cook, C.E., Adoutte, A., Akam, M., Carroll, S.B., Balavoine, G., 1999. Hox genes in brachiopods and priapulids and protostome evolution. Nature 399, 772-776.

Rowell, A.J., 1982. The monophyletic origin of Brachiopoda. Lethaia 15, 299-307.

Ruiz-Trillo, I., Ruitort, M., Fourcade, H.M., Baguna, J., Boore, J.L., 2004. Mitochondrial genome data support the basal position of Acoelomorpha and the polyphyly of the Platyhelminthes. Mol. Phylog. Evol. 33, 321-332.

Runnegar, B., Pojeta, J., Taylor, M.E., Collins, D., 1979. New species of the Cambrian and Ordovician chitons Matthevia and Chelodes from Wisconsin and Queensland: evidence for the early history of polyplacophoran molluscs. J. Paleontol. 53, 1374-1394. 
Saito, M., Kojima, S., Endo, K., 2000. Mitochondrial COI sequences of brachiopods: genetic code shared with protostomes; limits of utility for phylogenetic reconstruction. Mol. Phylog. Evol. 15, 331-344.

Sambrook, J., Fritsch, E.F., Maniatis, T., 1989. Molecular Cloning. a Laboratory Manual. Cold Spring Harbor Laboratory, Cold Spring Harbor, NY.

Sanderson, M.J., 2003. r8s: inferring absolute rates of molecular evolution and divergence times in the absence of a molecular clock. Bioinformatics 19, 301-302.

Schnare, M.N., Damberger, S.H., Gray, M.W., Gutell, R.R., 1996. Comprehensive comparison of structural characteristics in eukaryotic cytoplasmic large subunit (23S-like) ribosomal RNA. J. Mol. Biol. 256, 701-719.

Shimodaira, H., Hasegawa, M., 1999. Multiple comparisons of log-likelihoods with applications to phylogenetic inference. Mol. Biol. Evol. 16, 1114-1116.

Smith, A.G., Smith, D.G., Funnell, B.M., 1994a. Atlas of Mesozoic and Cenozoic Coastlines. Cambridge University Press, Cambridge.

Smith, S.W., Overbeek, R., Woese, C.R., Gilbert, W., Gillevet, P.M., 1994b. The Genetic Data Environment, an expandable GUI for multiple sequence analysis. Cabios 10, 671-675.

Steiner, G., Muller, M., 1996. What can 18S rDNA do for bivalve phylogeny? J. Mol. Evol. 43, 58-70.

Sundberg, P., Gibson, R., Olsson, U., 2003. Phylogenetic analysis of a group of palaeonemerteans (Nemertea) including two new species from Queensland and the Great Barrier Reef, Australia. Zool. Scripta 32, 279-296.

Swofford, D.L., 2000. Phylogenetic Analysis Using Parsimony (*and Other Methods). Sinauer Associates, Sunderland, MA.

Thompson, J.D., Gibson, T.J., Plewniak, F., Jeanmougin, F., Higgins, D.G., 1997. The CLUSTAL_X windows interface: flexible strategies for multiple sequence alignment aided by quality analysis tools. Nucleic Acids Res. 25, 4876-4882.

Williams, A., 1997. Shell structure. In: Kaesler, R.L. (Ed.), Treatise on Invertebrate Paleontology, Part H1, Brachiopoda, revised. Geological Society of America and University of Kansas, Boulder, Colorado and Lawrence, Kansas, pp. 267-320.

Williams, A., Wright, A.D., 1970. Shell structure of the Craniacea and other calcareous inarticulate Brachiopoda. Spec. Pap. Palaeontol. 7, 1-51.

Williams, A., Carlson, S.J., Brunton, H.C., Holmer, L., Popov, L., 1996. A supra-ordinal classification of the Brachiopoda. Phil. Trans. R. Soc. B 351, 1171-1193.

Williams, A., Cusack, M., Buckman, J.O., 1998. Siliceous tablets in the larval shells of apatitic discinid brachiopods. Science 279, 2094-2096.

Williams, A., Carlson, S.J., Brunton, C.H.C.B, 2000a. Craniiformea. In: Kaesler, R.L. (Ed.), Treatise on Inverte- brate Paleontology, Part H2, Brachiopoda, revised. Geological Society of America and University of Kansas, Boulder, Colorado and Lawrence, Kansas, pp. 158-192.

Williams, A., Carlson, S.J., Brunton, C.H.C.B, 2000 b. Linguliformea. In: Kaesler, R.L. (Ed.), Treatise on Invertebrate Paleontology, Part H2, Brachiopoda, revised. Geological Society of America and University of Kansas, Boulder, Colorado and Lawrence, Kansas, pp. 30-157.

Williams, A., Carlson, S.J., Brunton, C.H.C.B, 2000c. Rhynchonelliformea. In: Kaesler, R.L. (Ed.), Treatise on Invertebrate Paleontology, Part H2-5, Brachiopoda, revised. Geological Society of America and University of Kansas, Boulder, Colorado and Lawrence, Kansas, p. 193 in progress.

Williams, A., Lüter, C., Cusack, M., 2001. The nature of siliceous mosaics forming the first shell of the brachiopod Discinisca. J. Struct. Biol. 134, 25-34.

Winchell, C.J., Sullivan, J., Cameron, C.B., Swalla, B.J., Mallatt, J., 2002. Evaluating hypotheses of deuterostome phylogeny and chordate evolution with new LSU and SSU ribosomal DNA data. Mol. Biol. Evol. 19, 762-776.

Winnepenninckx, B., Backeljau, T., De Wachter, R., 1993. Complete small ribosomal subunit RNA sequence of the chiton Acanthopleura japonica. Nucleic Acids Res. 21, 1670 .

Winnepenninckx, B., Backeljau, T., De Wachter, R., 1994. Small ribosomal RNA and the phylogeny of the Mollusca. Nautilus (Suppl.) 2, 98-110.

Winnepenninckx, B., Backeljau, T., De Wachter, R., 1995a. Phylogeny of protostome worms derived from $18 S$ rRNA sequences. Mol. Biol. Evol. 12, 641-649.

Winnepenninckx, B., Backeljau, T., Mackey, L.Y., Brooks, J.M., De Wachter, R., Kumar, S., Garey, J.L., 1995b. 18S rRNA data indicate that aschelminths are polyphyletic in origin and consist of at least three distinct clades. Mol. Biol. Evol. 12, 1132-1137.

Winnepenninckx, B., Backeljau, T., van de Peer, Y., De Wachter, R., 1992. Structure of the small ribosomal subunit RNA of the pulmonate snail, Limicolaria kambeul, and phylogenetic analysis of the Metazoa. FEBS Lett. 309, 123-126.

Wray, G.A., Levinton, J.S., Shapiro, L.H., 1996. Molecular evidence for deep Precambrian divergences among metazoan phyla. Science 274, 568-573.

Xian-Guang, H., Aldridge, R.J., Bergström, J., Siveter, D.J., Xiang-Hong, F., 2004. The Cambrian Fossils of Chengjiang, China: the Flowering of Early Animal Life. Blackwell, Oxford.

Yatsu, N., 1902. On the development of Lingula anatina. J. Coll. Sci. Imp. Univ. (Tokyo) 17, 1-112 pls. 1-8.

Zrzavy, J., Mihulka, S., Kepka, P., Bezdek, A., Tietz, D., 1998. Phylogeny of the metazoa based on morphological and $18 \mathrm{~S}$ ribosomal DNA evidence. Cladistics 14, 249-285. 